\title{
The Judicial Power and Treaty Delegation
}

\author{
Michael P. Van Alstine†
}

In this Essay, Professor Van Alstine addresses the power of federal courts to develop the law within the scope of a treaty. In response to an earlier essay by Professor John Yoo in this Review, Professor Van Alstine first challenges the assertion that the President has the sole constitutional power to interpret all treaties. He argues that for those treaties that create directly enforceable domestic law, the Supremacy Clause and the judicial power of Article III of the Constitution allocate final authority over interpretation and application to the federal courts. Professor Van Alstine contends that the closest formal and functional analog for such self-executing treaties is Article I legislation. As a result, in parallel with established law with regard to statutory delegations, there is no constitutional infirmity in a deliberate and circumscribed delegation of common-law powers by the constitutional treaty-lawmakers (the President with a supermajority of the Senate). Respect for the important role of the executive branch in the conduct of foreign affairs may justify calibrated deference to the reasonable interpretive views of the President. Professor Van Alstine nonetheless explains that this respect does not displace the core judicial responsibility to interpret those treaties that create domestically enforceable rights nor invalidate a properly circumscribed delegation of an authority to develop the law within their scope.

\section{INTRODUCTION}

A formal treaty ratified in conformance with constitutionally prescribed procedures is the most concrete, and should be the least controversial, form of international legal cooperation. In recent years, however, the growth of social and economic interdependence on a global scale has led to a substantial increase in international cooperation on shared legal concerns. The result has been an expansion of treaty law into an ever broader field of

Copyright 92002 California Law Review, Inc. California Law Review, Inc. (CLR) is a California nonprofit corporation. CLR and the authors are solely responsible for the content of their publications.

$\dagger \quad$ Professor of Law, The University of Maryland. I wish to express my gratitude to the colleagues who commented on earlier drafts. Special thanks go to G. Gordon Young. I am indebted to Kate Christensen for her valuable research assistance on very short notice. 
governance. Matters such as extradition ${ }^{1}$ and taxation, ${ }^{2}$ for example, have joined the traditional treaty subjects of peace, arms control, and amity in international agreements commonly accepted by the United States. In the field of human rights as well, the United States has ratified numerous treaties designed to protect individual civil and political rights against abuse on both international and domestic levels. ${ }^{4}$ The United States also has ratified a number of less well-known, but nonetheless significant treaties mandating international cooperation on a variety of private-law matters, including civil procedure ${ }^{5}$ and family law. ${ }^{6}$ Similarly, in recent years, a broad range of conventions have emerged that are designed to unify the law governing international commercial transactions.?

1. The United States has ratified well over fifty extradition treaties with other countries. See 18 U.S.C. $\$ 3181(2000)$ (listing such treaties). For a particularly controversial interpretation of such an extradition treaty, see United States v. Alvarez-Machain, 504 U.S. 655 (1992) (holding that an extradition treaty between the United States and Mexico did not prohibit the forcible abduction of a Mexican citizen in Mexico by U.S. officials). See also Alvarez-Machain v. United States, 266 F.3d $1045,1050-52$ (9th Cir. 2001) (holding that this abduction and arbitrary detention nonetheless violated international law).

2. There are nearly fifty tax treaties in effect between the United States and its major trading partners. See Ernest R. Larkins, U.S. Income Tax Treaties in Research and Planning: A Primer, 18 VA. TAX REv. 133 app. (1998) (listing the tax treaties in effect between the United States and other countries).

3. The United States began concluding treaties of "Friendship, Commerce, and Navigation" with other countries as early as the beginning of the nineteenth century. See Treaties of Friendship. Commerce, and Navigation With Latin American Countries, 1 I.L.M. 91, 92-96 (1962) (listing treaties concluded between 1815 and 1962); see also 8 U.S.C. $\$ 1101$ (1994) (Treaties \& Conventions) (setting forth an updated partial list of such treaties).

4. Most recently, in 1994, the United States ratified the Convention Against Torture and Other Cruel, Inhuman or Degrading Treatment or Punishment. Annex, U.N. Doc. E/CN.4/1984/72. See Treaty Affalrs Staff, U.S. Dep't of State, Treaties in Force: A List of Treaties and Other INTERNATIONAL AGREEMENTS OF THE UNITED STATES IN FoRCE ON JANUARY I, 1999, at 466 (1999). For other human rights treaties ratified by the United States, see Mary Becker, Towards a Progressive Politics and a Progressive Constitution, 69 FordHAM L. REv. 2007, 2012-14 (2001) (citing the ratification by the United States of the Convention on the Elimination of All Forms of Racial Discrimination in 1994, The International Covenant on Civil and Political Rights in 1992, and the International Convention on the Prevention and Punishment of the Criine of Genocide in 1986).

5. See, e.g., Convention on the Taking of Evidence Abroad in Civil or Commercial Matters, opened for signature Mar. 18, 1970, 23 U.S.T. 2555; Convention on the Service Abroad of Judicial and Extrajudicial Documents in Civil or Commercial Matters, opened for signature Nov. 15, 1965, 20 U.S.T. 361 .

6. See, e.g., Convention on the Civil Aspects of International Child Abduction, concluded Oct. 25, 1980, T.A.I.S. NO. 11, 670. Most recently, the Senate gave its advice and consent to the Convention on Protection of Children and Cooperation in Respect of Intercountry Adoption, concluded May 29, 1993, S. Treaty Doc. 105-51, at III (1998).

7. The most prominent of these is the United Nations Convention on Contracts for the International Sale of Goods [hereinafter C1SG], opened for signature Apr. 11, 1980, 1489 U.N.T.S. 3, which the United States ratified in 1986 . I analyze this convention and its commercial law progeny at length in Part II.B. See infra notes 180-99 and accompanying text. 
Because, unlike in some other countries, ${ }^{8}$ treaties in the United States can have a direct and immediate effect of their own force, they potentially provide a powerful vehicle for legal change. The Supremacy Clause elevates treaties to "the supreine Law of the Land." When properly approved and ratified, ${ }^{10}$ therefore, their substantive provisions can both preempt conflicting state law and even displace earlier federal statutes. ${ }^{11}$ As a result, the recent expansion of treaty law has spawned increasingly heated academic debates over the proper scope of the treaty power. ${ }^{12}$

These debates thus far have distilled into two main controversies. The first, which principally proceeds from notions of federalism, challenges the accepted view that there are no substantive limitations on the use of the treaty power to displace state law. ${ }^{13}$ The second, separate debate, propelled principally by Professor John Yoo, argues that, absent further implementing legislation, the structure of the Constitution precludes judicial enforcement of a treaty within the scope of Congress's Article I powers. ${ }^{14}$

8. See Richard B. Lillich, Invoking International Human Rights Law in Domestic Courts, $54 \mathrm{U}$. CrN. L. REv. 367, 373 (1985) (observing that "relatively few countries have adopted the doctrine of self-executing treaties"); Stefan A. Riesenfeld \& Frederick M. Abbott, The Scope of U.S. Senate Control Over the Conclusion and Operation of Treaties, 67 CHI-KENT L. REv. 571, 575 (1991) (observing that in some countries, "such as the United Kingdom, treaties... require parliamentary action before the courts will recognize individual rights"). I review the distinction in the United States between so-called self-executing and non-self-executing treaties infra notes 50-71 and accompanying text.

9. U.S. ConsT. art. VI, § 1, cl. 2 ("This Constitution, and the Laws of the United States which shall be made in Pursuance thereof; and all Treaties made, or which shall be made, under the Authority of the United States, shall be the supreme Law of the Land ....").

10. See U.S. CONST. art. II, $\$ 2$.

11. See Whitney v. Robertson, 124 U.S. 190, 194 (1888) (stating that when an act of legislation conflicts with the self-executing provisions of a treaty, "the one last in date will control the other"); see also Breard v. Greene, 523 U.S. 371, 376 (1998) ("[A]n Act of Congress ... is on a full parity with a treaty" and "when a statute which is subsequent in time is inconsistent with a treaty, the statute to the extent of conflict renders the treaty null.") (quoting Reid v. Covert, 354 U.S. 1, 18 (1957)).

12. U.S. CONST. art. II, $\S 2$, cl. 2.

13. See Curtis A. Bradley, The Treaty Power and American Federalism, 97 Mrch. L. Rev. 390 (1998) (arguing that interests of federalisun reflected in the notion of a national government of enumerated powers place substantive limits on the scope of the treaty power); David M. Golove, Treaty-Making and the Nation: The Historical Foundations of the Nationalist Conception of the Treaty Power, 98 MiCH. L. REv. 1075 (2000) (disagreeing with Professor Bradley's arguments on the basis of an historical analysis of the treaty power and a textual and structural analysis of the Constitution); Curtis A. Bradley, The Treaty Power and American Federalism, Part II, 99 Mrch. L. REv. 98 (2000) (responding that Professor Golove's criticisins are inconsistent with recent Supreme Court federalisn decisions).

14. See John C. Yoo, Globalism and the Constitution: Treaties, Non-Self-Execution, and the Original Understanding, 99 Colum. L. Rev. 1955 (1999) [hereinafter Yoo, Non-Self-Execution]; John C. Yoo, Treaties and Public Lawmaking: A Textual and Structural Defense of Non-Self-Execution, 99 CoLUM. L. REv. 2218 (1999) [hereinafter Yoo, Treaties and Public Lawmaking]; see also Martin S. Flaherty, History Right?: Historical Scholarship, Original Understanding, and Treaties as "Supreme Law of the Land", 99 CoLum. L. REv. 2095 (1999); Carlos Manuel Vazquez, Laughing at Treaties, 99 Colum. L. Rev. 2154 (1999). 
In a recent essay in this Review, Professor Yoo addresses a new issue, the formal and functional considerations that govern treaty interpretation..$^{15}$ In light of the expanding scope of treaties in our legal system, this issue carries the potential to become both practically more significant and substantively more controversial than in the past. Surprisingly, however, the matter of treaty interpretation has thus far received only limited scholarly attention. ${ }^{16}$ This fact is all the more curious, as Professor Yoo notes, ${ }^{17}$ given that the parallel subject of statutory interpretation is now one of the most animated themes of American legal thought. ${ }^{18}$

Professor Yoo bases his analysis of treaty interpretation on a reevaluation ${ }^{19}$ of a heated, historical debate during the Reagan administration over the power of the President to reinterpret the Anti-Ballistic Missile Treaty ("ABM") between the United States and what was then the U.S.S.R. ${ }^{20}$ Briefly, Professor Yoo's position is that formal and functional constitutional considerations lead to the conclusion that the President has "unilateral freedom to interpret and reinterpret treaties." his argument, Professor Yoo also challenges the notion that the federal courts could have a substantial role to play in the development of treaty

15. John Yoo, Politics as Law?: The Anti-Ballistic Missile Treaty, the Separation of Powers, and Treaty Interpretation, 89 CALIF. L. Rev. 851 (2001) [hereinafter Yoo, Politics as Law].

16. See David J. Bederman, Revivalist Canons and Treaty Interpretation, 41 UCLA L. Rev. 953 (1994); Michael P. Van Alstine, Dynamic Treaty Interpretation, 146 U. PA. L. Rev. 687 (1998); James C. Wolf, Jurisprudence of Treaty Interpretation, 21 U.C. DAvIS L. REv. 1023 (1988).

17. See Yoo, Politics as Law, supra note 15 , at 879 n. 85 .

18. For an introduction into the eontentious literature on this subject, see William N. Eskridge, Jr. \& Philip P. Frickey, Statutory Interpretation as Practical Reasoning, 42 STAN. L. REV. 321 (1990); William N. Eskridge, Jr., Dynamic Statutory Interpretation, 135 U. PA. L. REv. 1479 (1987); Cass R. Sunstein, Interpreting Statutes in the Regulatory State, 103 HARv. L. REv. 405, 426-28 (1989). Perhaps the most spirited debate over statutory interpretation concerns the proper role of legislative history in interpretive inquiries. See ANTONIN SCALIA, A MATtER of INTERPRETATION 30-35 (1997) (criticizing the use of legislative history); Frank H. Easterbrook, Text, History, and Structure in Statutory Interpretation, 17 HARv. J.L. \& PuB. PoL'Y 61, 68-70 (1994) (same); William N. Eskridge, Jr., The New Textualism, 37 UCLA L. REv. 621 (1990) (comprehensively reviewing the emergence of textualist approaches to statutory interpretation).

19. As Professor Yoo describes in some detail, a suggestion by the Reagan administration that it had the right to reinterpret the Anti-Ballistic Missile Treaty sparked a contentious debate in both political circles and legal scholarship. See Yoo, Politics as Law, supra note 15, at 851-68 (describing the controversy at the time). For an introduction to the scholarly debate on this subject, see Lawrence J. Block et al., The Senate's Pie-in-the-Sky Treaty Interpretation: Power and the Quest for Legislative Supremacy, 137 U. PA. L. REv. 1481 (1989); David A. Koplow, Constitutional Bait and Switch: Executive Reinterpretation of Arms Control Treaties, 137 U. PA. L. Rev. 1353 (1989); Eugene V. Rostow, The Reinterpretation Debate and Constitutional Law, 137 U. PA. L. REv. 1451 (1989).

20. Treaty on the Limitation of Anti-Ballistic Missile Systems, May 26, 1972, U.S.-U.S.S.R., 23 U.S.T. 3435.

21. Yoo, Politics as Low, supra note 15, at 868 ("[B]oth formalist and functionalist approaches to the separation of powers lead to the conclusion that the President ought to have the unilateral freedom to interpret and reinterpret treaties."); see also id. at 865 ("Whether we apply textualist or dynamic notions of interpretation to treaties, it is clear that the President must enjoy the power to interpret international agreements on behalf of the nation."). 
law..$^{22}$ I advanced an argument in support of that notion in an earlier work entitled Dynamic Treaty Interpretation. ${ }^{23}$ Specifically, I argued there that certain private-law treaties delegate to federal courts the authority to develop the law within the treaties' scope. ${ }^{24}$

In his essay, Professor Yoo questions the constitutional foundation for such an argument. The notion of a delegation of common-law powers through treaties, he asserts, "suffers from [a] failure to identify any constitutional authorization for such an enormous transfer of power from the treatymakers to the courts....25 Indeed, he suggests that such a delegation "would arguably violate the Constitution if undertaken domestically."26 Professor Yoo raises an excellent question, indeed one for which there is virtually no other scholarly commentary and only limited judicial authority. Here, I take up a general response to his challenge.

My argument proceeds in three principal parts. Part I responds to the formal assertion that all treaties are fundamentally executive in nature, as well as its consequence that treaty interpretation is a matter within the unilateral control of the President. Specifically, I argue that if limited to those treaties that solely create sovereign obligations on the international plane, ${ }^{27}$ there may be some merit in this point. ${ }^{28}$ But for those treaties that create rights or obligations directly enforceable as domestic law, I contend that the closest formal and functional analog is Article I legislation. For such treaties, the Supremacy Clause and the judicial power in Article III together allocate the final authority over their application and interpretation to the courts. ${ }^{29}$

Part II of this Essay then turns to the constitutionality of delegation to the federal courts of an enhanced interpretive power to develop the law within the scope of a treaty. Substantial, compelling authority now supports the proposition that separation of powers and federalism concerns do not prohibit Congress's deliberate and circumscribed dclegation of a similar power through Article I legislation..$^{30}$ I will argne in Part II that those treaties that create rights enforceable by individuals in domestic courts,

22. Yoo, Politics as Law, supra note 15 , at 879 n. 85 .

23. Van Alstine, supra note 16, at 753-58.

24. Id.

25. Yoo, Politics as Law, supra note 15, at 879 n.85.

26. Id.

27. Professor Yoo seems to suggest such a qualification at the conclusion of his work. See id. at 914 (" $[\mathrm{A}]$ large number of treaties, especially arms control and politico-military agreements, do not create any legally-enforceable rights for individuals, but rather regulate the international relations between two or more nation-states. As such, they represent political arrangements, not domestic law.").

28. See infra notes 52-54 and accoinpanying text.

29. See infra notes 72-82 and accompanying text.

30. See infra Part II.A. 
which are properly viewed as "equivalent to an act of the legislature," reflect a compelling parallel with the constitutional foundation for delegation in the statutory context. As a result, there is no constitutional infirmity in a deliberate and circumscribed delegation to the federal courts of a power to develop the law within the scope of such treaties. ${ }^{32}$ Indeed, a clear example of such a delegation under a treaty already exists. As we shall see in Part II.B, the private-law conventions analyzed in Dynamic Treaty Interpretation expressly authorize the courts to fill the gaps in their regulatory scheme as they emerge through judicial examination over time. ${ }^{33}$

Finally, Part III addresses Professor Yoo's claim that functional considerations mandate absolute deference to the President in the interpretation of treaties. I will argue that, while the executive branch may have structural advantages over the judicial branch in interpreting those treaties that address national defense, diplomacy, and similar matters at the core of our nation's foreign policy, all treaties do not raise such concerns equally. Arguments founded on executive preeminence in foreign affairs, while important in some contexts, dissolve in others. ${ }^{34}$ Likewise, for some treaties, such as the private commercial law conventions discussed in Dynamic Treaty Interpretation, ${ }^{35}$ there is little reason to assume any special executive-branch expertise as compared to the traditional means of interpretation through domestic judicial proceedings. ${ }^{36}$ In short, while some form of calibrated deference may be appropriate, foreign affairs and executive expertise rhetoric does not justify absolute judicial abdication in favor of fleeting executive views on the interpretation of all treaties.

\section{The Judicial Power and Treaty InTERPRetation}

Professor Yoo's point of departure on the subject of treaty interpretation is a series of formal arguments about the nature of treaties in our constitutional system. His core contention is that the placement of the Treaty Clause in Article II of the Constitution "indicates that the power to make treaties, and by extension to interpret them, remains an executive one." $\mathrm{He}$ bolsters this argument by citing to the Vesting Clause in Article I, Section $1 .^{38}$ Because that clause limits the legislative powers allocated to

31. Foster v. Neilson, 27 U.S. 253,314 (1829). 1 explore this observation in greater detail infra notes 149-64 and accompanying text.

32. See infra Part 11.B.

33. See infra notes $179-90$ and accompanying text.

34. See infra notes 233-36 and accompanying text.

35. See Van Alstine, supra note 16, at 753-58.

36. I discuss this point in greater detail, infra notes 243-47 and accompanying text.

37. See Yoo, Politics as Law, supra note 15, at 870; see also id. at 869 ("A textual examination of the Constitution indicates that the treaty power is fundamentally executive in nature.").

38. U.S. CoNST. art. I, $\S 1$ ("All legislative Powers herein granted shall be vested in a Congress of the United States...."). 
Congress to those "herein granted," he reasons that any powers found in Article II (such as the treaty power) cannot be legislative in nature. ${ }^{39}$ To be sure, the Constitution mandates the participation of a legislative institution (the Senate) in the treaty-making process. ${ }^{40}$ In his view, however, this participation merely reveals that the Senate plays a role in the exercise of executive functions, and not that treaty making is a legislative power. ${ }^{41}$

The principal target of Professor Yoo's observations appears to be the balance of power between the executive and legislative branches in matters of treaty interpretation. ${ }^{42}$ But his argument that the treaty power's location in Article II implies that the President has "unilateral authority"43 to interpret (and reinterpret) treaties has significant implications for the role of the judiciary as well. If his formal argument is correct, then there are derivative limitations on the traditional judicial responsibility in that context "to say what the law is." 94

Before examining the propriety of a delegation of common-law powers through the vehicle of a treaty, therefore, we must first determine the fundamental nature of treaties, and thus the allocation of authority over their interpretation, in our constitutional structure.

\section{A. The Nature of Treaties}

The first step in our analysis is a familiar, but nonetheless essential, one. As Professor Yoo has analyzed in some detail, prior to the Framing, treaties were traditionally understood to be mere contracts between sovereign nations. ${ }^{45}$ Professor Yoo thus quotes Alexander Hamilton in Federalist

39. See Yoo, Politics as Law, supra note 15, at 869 ("In order to give every word in the Constitution meaning, we should construe th[e] 'herein granted' language as liniting Congress's legislative powers to the list enumerated in Article 1, Section 8, while Article 11's Vesting Clause must refer to inherent Executive and judicial powers unenumerated elsewhere in the document.").

40. U.S. ConsT. art. II, $\S 2$, cl. 2 (conferring upon the President "the Power, by and with the Advice and Consent of the Senate, to make Treaties, provided two thirds of the Senators present concur").

41. See Yoo, Politics as Law, supra note 15, at 869 ("[T] $]$ he Senate's participation in treaty making and appointments merely indicates the dilution of the unitary nature of the executive branch, rather than the transformation of these functions into legislative powers."); see also id. at 870 ("The Senate's advice and consent power does not transform the treaty power into a legislative function; instead, it makes the Senate part of the Executive branch for purposes of making international agreements.").

42. See id. at 874 (suggesting that the focus was on the propriety of "[g]ranting the President the power to interpret treaties without the Senate's consent..."); id. at 875 (arguing that becanse of executive dominance in foreigu affairs "there seems to be little constitutional reason to privilege Senate understandings of the text [of the ABM Treaty] over those promoted by the President").

43. See id. at 868; id. at 878 (arguing that the President should have "unilateral authority to reinterpret treaties").

44. Marbury v. Madison, 5 U.S. (1 Cranch) 137, 177 (1803).

45. See Yoo, Non-Self-Execution, supra note 14, at 1982-2069; Yoo, Politics as Law, supra note 15, at 882-901. But see Flaherty, supra note 14, at 2105-51 (comprehensively challenging Professor Yoo's historical analysis of the treaty power). 
No. 75 , who noted that "the essence of the legislative authority is to enact laws, or in other words to prescribe rules for the regulation of the society," whereas the objects of treaties, "are CONTRACTS with foreign nations ...."46 Because their essential nature involved sovereign actors defining their own obligations to entities external to their own legal systems, therefore, treaties refiected something fundamentally other than domestic law. ${ }^{47}$ In other words, this international (that is, external) contract paradigm held that treaties derive their force as law not from domestic sources, but rather from an elastic duty of "good faith" owed merely to foreign sovereigns. ${ }^{48}$

The Supremacy Clause and Article 11I, however, marked a departure from this traditional model. Without express limitation, Article VI provides that the Constitution, laws, and "all Treaties" shall be "the supreme Law of the Land. ${ }^{349}$ To carry this equivalent status into effect, Article III establishes that the judicial power extends not only to cases arising under the Constitution and laws of the United States, but also to "treaties made, or which shall be made, under their Authority." 50 The inclusion within the judicial power in Article III thus placed treaties on an equal footing with Article I laws.

Beginning with some of its earliest examinations of the subject, the Supreme Court recognizcd that in the United States, treaties may function as more than mere contracts betwcen sovereigns. The Court's opinion in Foster v. Neilson remains pcrhaps the clearest statement of this recognition:

A treaty is in its nature a contract between two nations, not a legislative act. It does not generally effect, of itself, the object to be accomplished.... In the United States a different principle is established. Our Constitution declares a treaty to be the law of the land. It is, consequently, to be regarded in courts of justice as equivalent to an act of the legislature, whcnever it operates of itsclf without the aid of any legislative provision. ${ }^{51}$

46. Yoo, Politics as Law, supra note 15, at 892 (quoting The Federalist No. 75, at 504 (Alexander Hamilton) (Jacob E. Cooke ed., 1961)).

47. Sce Bederman, supra note 16, at 954 ("The strange birth and schizophrenic life of treaties has caused them to be seen as something fundamentally other than public law.").

48. See The Federalist No. 75, at 504 (Alexander Hamilton) (Jacob E. Cooke ed., 1961) ("Treaties have the force of law, but derive it from the obligations of good faith."); see also Yoo, Politics as Law, supra note 15, at 892 (setting forth this quote by Hamilton); Carlos Manuel Vazquez, Treaty-based Rights and Remedies of Individuals, 92 CoLum. L. Rev. 1082, 1082 (1992) [heremafter Vazquez, Treaty Rights] (noting the widely held view regarding their international effect "that treaties, as international instruments, establish legal obligations and correlative legal rights only of the nations that are parties to them, not of individuals").

49. U.S. ConST. art. Vl, § l, cl. 2.

50. U.S. Const. art. IIl, § 2, cl. 1 .

51. 27 U.S. 253,314 (1829). 
As this foundational pronouncement of the Supreme Court makes clear, the significant diversity in treaty substance precludes any reliable generalizations about the fundamental nature of all treaties. ${ }^{52}$ Some treaties may indeed solely "import a contract." ${ }^{.53}$ That is, they may involve merely a promise by the United States as a sovereign entity to a foreign sovereign. In such a case, the treaty may indeed "address[] itself to the political, not the judicial department." 54

This "sovereign contract" paradigm collapses, however, when generalized beyond that specific class of treaties. Some treaties create rights that are enforceable directly by individuals in domestic courts. From a formal perspective, the Supremacy Clause gives such treaties the force of law, indeed the supreme law of the land. Moreover, Article 111 makes clear that the judicial power, which of its essence is the interpretive authority "to say what the law is,"55 extends to treaties as well. As part of the law of the land, these domestically enforceable treaties must also fall within the executive's obligation in Article II, Section 3 to "take care" that the "Laws" are faithfully executed. ${ }^{56}$

As a result, until terminated, ${ }^{57}$ their provisions should bind the President just as does any other form of extant federal law. ${ }^{58}$ As Professor

52. If one follows the alternate suggestion advanced by Professor Yoo that (beyond a mere "soft" mle presumption against self-execution) the structural Constitution entirely prohibits self-executing treaties, at least on matters withm Congress's Article I, Section 8 authority, the possibility for treaties of a legislative nature radically diminishes. See Yoo, Non-Self-Execution, supra note 14, at 2092 (suggesting the possibility of such an approach); Yoo, Treaties and Public Lawmaking, supra note 14, at 2220 (describing this approach as a "hard" rule by which "[t]reaties cannot receive judicial enforcement in areas that fall within Congress's Article I, Section 8 powers, without statutory implementation by Congress"). Stripped of this possibility, the debate over self-execution in our constitutional system focuses upon the question of what standards courts should apply to distinguish between those treaties that create immediately enforceable domestic law rights and those that do not. While important, this question ultimately does not control the separate issue analyzed here of whether, for those treaties that do create such rights in accordance with the constitutionally prescribed standards, a treaty may delegate to the judiciary enhanced interpretive authority for matters within their scope.

53. Foster v. Neilson, 27 U.S. 253, 314 (1829).

54. Id. at 314; see also Cherokee Nation v. Georgia, 30 U.S. 1, 30 (1831) ("There is then a great deal of sense in the [traditional] rule... that as between sovereigns, breaches of treaty were not breaches of contract cognizable in a court of justice....").

55. Marbury v. Madison, 5 U.S. (1 Cranch) 137, 177 (1803).

56. U.S. Const. art. II, $\$ 3$ (requiring that the President "shall take Care that the Laws be faithfully executed"); see also Curtis A. Bradley, Chevron Deference and Foreign Affairs, 86 VA. L. Rev. 649, 655 (2000) [hereinafter Bradley, Chevron Deference] (stating that self-executing treaties "presumably are also part of the 'Laws' referred to in Article II's Take Care Clause").

57. Professor Yoo has argued that the President should have a unilateral authority to terminate treaties. See Yoo, Politics as Law, supra note 15, at 873-74 ("Although the constitutional text is silent on the issue, most commentators, courts, and government entities believe that the President may terminate a treaty unilaterally.") (citing, inter alia, Goldwater v. Carter, 481 F. Supp. 949 (D.D.C. 1979), rev'd, 617 F.2d 697 (D.C. Cir. 1979), vacated as moot, 444 U.S. 996 (1979)). Once again, there may be merit in this observation with regard to treaties that solely create international, contract-like obligations to foreigu nations. From a formal constitutional perspective, however, there is reason to question the authority of the President to unilaterally terminate treaties that have created rights 
Carlos Vazquez has observed, the inclusion of treaties within Article III and the Supremacy Clause "altered-or made irrelevant-for domestic purposes those attributes of treaties that distinguished them from laws: it made them operative on individuals and enforceable in the courts by individuals." 59 And indeed, in nearly all cases that have come before it, the Supreme Court has either expressly found that a treaty creates enforceable rights of individuals or has proceeded directly to interpret and apply a treaty without even raising the issue. ${ }^{60}$

The extension of the judicial power of Article III to treaties does not mean, however, that individuals may enforce any treaty at any time. ${ }^{61}$ Rather, building on the premise of Foster v. Neilson, the Supreme Court has long distinguished between what have come to be known as selfexecuting and non-self-executing treaties, that is, between those that are directly enforceable by individuals in domestic courts and those that are not. ${ }^{62}$ The doctrine of non-self-execution holds that, just like other forms of domestic law, ${ }^{63}$ examination of the substance of a treaty may reveal that its

enforceable as domestic law. As the Supreme Court has recently and emphatically stated in the structurally parallel case of the Line-Item Veto Act, "[t]here is no provision in the Constitution that authorizes the President to enact, to amend, or to repeal statutes." Clinton v. City of New York, 524 U.S. 417, 438 (1998). Cf. Bradley, Chevron Deference, supra note 56, at 655-56 "Whether the Executive branch has the power to unilaterally terminate a treaty (and thereby avoid the domestic-law obligation to comply with it) has not been resolved.").

58. See Bradley, Cheveron Deference, supra note 56, at 655 (making the same observation).

59. Vazquez, Treaty Rights, supra note 48, at 1108-09.

60. For a canvassing of Supreme Court authority on these points, see Carlos Manuel Vazquez, The Four Doctrines of Self-Executing Treaties, 89 AM. J. 1NT'L. L. 695, 716 n.96 (1995) [hercinafter Vazquez, Four Doctrines] (arguing that, other than the subsequently reversed decision in Foster $v$. Neilson, the Supreme Court has only once denied relief because a treaty was not self-executing, and even that decision was ambiguous). See also id. (citing a number of cases in which the Supreme Court expressly found that a treaty was self-executing); $i d$. (citing numerous additional cases in which the Court interpreted a treaty without even questioning that it was enforceable by the courts). Separately, the Supreme Court has expressly found that, notwithstanding the political question doctrine, courts have the authority to interpret treaties. See Japan Whaling Ass'n v. Am. Cetacean Soc'y, 478 U.S. 221, 230 (1986).

61. See Vazquez, Four Doctrines, supra note 60, 699 ("The recognition that treaties, along with the Constitution and federal statutes, are 'law' and therefore enforceable by the courts without prior legislative transformation into domestic law does not, of course, inean that treaties may be cnforced in court by any individual at any time.").

62. See, e.g., Terlinden v. Ames, 184 U.S. 270, 288 (1902) (noting the distinction); The Head Money Cases, 112 U.S. 580, 598 (1884) (observing that the Constitution places self-cxecuting treaties in the same category as other laws of Congress that create rights "capable of enforcennent as between private parties"); Foster v. Neilson, 27 U.S. 253, 314 (1829) (holding that a treaty is to be regarded as "equivalent to an act of the legislature, whenever it operates of itself without the aid of any legislative provision").

63. A phenomenon that parallels the doctrine of non-self-executing treaties exists with certain statutory delegations to administrative agencies of the discretion to adopt implementing regulations. Although the statutory authorization qualifies as law, no enforceable individual rights or obligations exist until the agency decides to exercise its authority to issue the regulations. See also Yoo, Treaties and Public Lawmaking, supra note 14, at 2244-48 (discussing the various aspects of statutory law that are not immediately enforceable by federal courts). 
provisions are not (or not yet) amenable to judicial enforcement in domestic courts. Some non-self-executing treaties, for example, may be merely precatory or otherwise too vague for judicial enforcement. ${ }^{64}$ Some may address political issues over which courts properly hesitate to exercise jurisdiction in the absence of particularly clear guidance. ${ }^{65}$ Others may delegate to Congress the decision as to whether, and if so to what extent, they should be given force as domestic law through Article I legislation. ${ }^{66}$ Still others may not be enforceable because of a more conspicuous absence, both $\mathrm{m}$ their own provisions and by reference to other sources of law, of a private right of action for imdividuals ${ }^{67}$ In all these cases, even though the Senate has properly given its consent, the substance of the treaties reveals that the discretion concerning the timing and means of their enforcement has first been entrusted to constitutional institutions other than the federal judiciary. ${ }^{68}$

The particular constitutional constramts on the recognition of treaties as enforceable domestic law have been the subject of exhaustive historical

64. See, e.g., INS v. Cardoza-Fonseca, 480 U.S. 421,441 (1987) (examining the distinction between mandatory obligations and mere precatory provisions under the United Nations Protocol Relating to the Status of Refugees); Sei Fujii v. California, $38 \mathrm{Cal} .2 \mathrm{~d} \mathrm{718,721-25} \mathrm{(1952)} \mathrm{(holding} \mathrm{that}$ the provisions of the United Nations Charter were too vague to be self-executing). In this sense, there is a parallel between the notion that the provisions of a treaty may be too vague for enforcement and one aspect of the political question doctrine that asks whether there are "judicially discoverable and manageable standards." See Baker v. Carr, 369 U.S. 186, 217 (1962); see also Vazquez, Four Doctrines, supra note 60, at 713-15 (exploring the same parallel); Vazquez, Treaty Rights, supra note 48 , at $1130-33$ (same).

65. Arms control treaties and the like, involving core questions of national security, may well fall vithin a class whose political nature places them beyond judicial enforcement (and thus interpretation) absent clear evidence to the contrary. See also Vazquez, Four Doctrines, supra note 60, at 717. Professor Vazquez suggests that "certain treaties" may not be

judicially enforceable under our Constitution because they bear too closely on national security or are otherwise too sensitive for judicial involvement. A claim that an arms control agreement requires the United States to dismantle weapons, for example, might be Id. nonjusticiable on this ground even if the agreement is neither precatory nor vague.

66. See Vazquez, Treaty Rights, supra note 48, at 1125-29 (discussing the "prototype of a nonself-executing treaty" as one that does not create enforceable rights of its own accord, but rather "delegates" law-making authority to Congress).

67. See Vazquez, Four Doctrines, supra note 60, at 719-21.

68. Some commentators have argued that the very notion of a non-self-executing treaty is unconstitutional because the Supremacy Clause elevates all treaties to the supreme law of the land. See, e.g., Jordan J. Paust, Self-Executing Treaties, 82 AM. J. INT'L L. 760, 760 (1988) (arguing that "[t]he distinction found in certam cases between 'self-executing' and 'non-self-executing' treaties is a judicially invented notion that is patently imconsistent with express language in the Constitution affirming that "all Treaties ... shall be the supreme Law of the Land"'); Charles H. Dearborn III, Note, The Domestic Legal Effect of Declarations that Treaty Provisions Are Not Self-Executing, 57 TEx. L. REv. 233, 233-34 (1979) (arguing that declarations attached upon Senate consent that a treaty is not self-executing "are of dubious validity, probably have no binding effect on United States courts, and should not be used as aids in construing the treaties"). 
and structural analysis by Professor Yoo and his critics. ${ }^{69}$ We need not wade into the thicket of this thorny debate over whether the Constitution requires a presumption for or against self-execution, however, to extract the broader principle. ${ }^{70}$ For our purposes here it is sufficient to observe, in accordance with established Supreme Court precedent, ${ }^{71}$ that some, though not all, treaties create rights or obligations that are directly enforceable as domestic law in federal courts.

\section{B. Treaty Interpretation}

Contrary to the sovereign contract paradigm, therefore, self-executing treaties are properly viewed as the formal and functional equivalent of Article I legislation. ${ }^{72}$ Like statutory law, these treaties by definition involve the government's creation of individual rights (or obligations), and are enforceable in court at the behest of or against individuals. To return to the quote from Alexander Hamilton, such treaties reflect "the essence of the legislative authority," for they directly "prescribe rules for the regulation of the society."73

In accordance with this reasoning, the Supreme Court itself has long recognized that the role of the courts in the application of a self-executing treaty is functionally identical to that for Article I legislation. Indeed, in its foundational pronouncement in Foster v. Neilson, the Court described such a treaty as "equivalent to an act of the legislature." case of Whitney $v$. Robertson, the Court einphasized that where treaty provisions "are self-executing, that is, require no legislation to make them

69. See generally Yoo, Non-Self-Execution, supra note 14 (challenging the traditional acceptance of sclf-executing treaties on the basis of an analysis of the historical background and structure of the Constitution). But see Flaherty, supra note 14, at 2105-51 (disagreeing with Professor Yoo's historical account); Vazquez, supra note 14, at 2158-68 (same).

70. See Yoo, Non-Self-Execution, supra note 14, at 2092 (concluding that there should at least be a "presumption" against self-execution); Yoo, Treaties and Public Lawmaking, supra note 14, at 2220 (describing a "soft" rule, under which "courts can remain true to the text, structure, and original understanding of the Constitution by requiring the treaty-makers to issue a clear statement if they want a treaty to be self-executing"). But see Vazquez, supra note 14, at 2157-58 (concluding, even after reviewing the Supreme Court authority cited by Professor Yoo, that the Supremacy Clause "adopt[s] a default rule that treaties have the force of domestic law, a rule that may be reversed by the treatymakers through a clear statement in the treaty itself (or reservation thereto)").

71. See supra note 62 (citing such authority).

72. See also Vazquez, supra note 14, at 2210-11 (arguing in response to Professor Yoo's structural constitutional arguments that "if we equate 'legislation' and 'law' ... then the combination of Articles $\mathrm{ll}$ and VI would produce a clear allocation of legislative power to the President (and Senate)").

73. See The Federal1st No. 75, at 504 (Alexander Hamilton) (Jacob E. Cooke ed., 1961); see also Flaherty, supra note 14, at 2138-39 (analyzing the background and context of this quote in greater detail); The Federalist No. 33, at 202 (Alexander Hamilton) (Climton Rossiter ed., 1961) (arguing that "[w]hat is a LEGISLATIVE power but a power of making LAWS?").

74. 27 U.S. 253, 314 (1829). 
operative ... they have the force and effect of a legislative enactment." The Court was even more explicit in the The Head Money Cases. ${ }^{76}$ There, in the process of drawing a contrast to mere sovereign contracts, it concluded that treaty provisions that create individual rights "partake of the nature of municipal law... [and] the Constitution of the United States places such provisions as these in the same category as other laws of Congress." When, then, the rights created by a treaty "are of a nature to be enforced in a court of justice, that court resorts to the treaty for a rule of decision for the case before it as it would to a statute."

To be sure, treaties come into being through an Article II process formally initiated by the President ${ }^{79}$ that differs from that for Article I legislation. But, significantly, where the President initiates the Article II process for the creation of law, the Constitution also requires the involvenent of the legislature, namely a supermajority of the Senate, before a treaty can obtain the force of domestic law. Moreover, the Supremacy Clause expressly provides that, for those treaties whose substance so directs, the constitutional product of the Article II process is the same as Article I lawmaking. ${ }^{80}$ When a treaty addresses itself to the courts, therefore, Article III requires that they apply it just as they would a statute or any other form of judicially enforceable law.

Professor Yoo's response to this well-established constitutional law is to assert simply that the treaty power is found im Article II. In his view, because Article II vests executive power in the President, ${ }^{81}$ the mere

75. 124 U.S. 190, 194 (1888). Professor Louis Henkin has also equated self-executing treaties with legislation. See Louis Henkin, The Treaty Makers and the Law Makers: The Niagara Reservation, 56 CoLUm. L. Rev. 1151, 1169 (1956) (arguing that "Article VI establishes that the treaty power includes an important power to legislate domestically"). See also Golove, supra note 13, at 1286. Golove observed that

[t]he treaty power empowers the President and Senate, incident to making agreements with foreign states, to promulgate laws. As a result, whenever a treaty makes stipulations on subjects falling within the scope of Congress's legislative authorities, the treaty overrides the Id. general separation of powers principle that legislative authority is vested in Congress.

76. 112 U.S. 580 (1884).

77. Id. at 598 .

78. Id. at 599; see also Strother v. Lucas, 37 U.S. 410,439 (1838) ("Treaties are the law of the land, and a rule of decision in all courts.").

79. There has been some debate over whether the intent behind "advice" language in the Treaty Clause requires the Senate's active participation from the very beginning of the treaty-making process. But, as Professor Yoo correctly observes, actual practice after the adoption of the Constitution quickly excluded formal Senate involvement until after negotiations were completed. See Yoo, Politics as Law, supra note 15 , at $895-901$.

80. To overcome the clear text of the Supremacy Clause, Professor Yoo is forced to suggest an "alternate approach to the Supremacy Clause" under which the political branches, instead of the courts, could be the institutions obligated to enforce treaty law. See Yoo, Treaties and Public Lawmaking, supra note 14, at 2249-53 (advancing this argument). But see Vazquez, Laughing at Treaties, supra note 14, at 2169-73 (challenging Professor Yoo's textual reading of the Constitution, in particular, the Supremacy Clause, with regard to treaties).

81. See U.S. CoNST. art. II, § 1 . 
placement in that article of the power to make treaties must mean that the sole constitutional authority over the interpretation (and reinterpretation) of all treaties also resides with the President. ${ }^{82}$ This hyperstructuralist view is unconvincing for a number of reasons.

First, the text and structure of the Constitution beyond Article II is inconsistent with Professor Yoo's attempt to reason "by extension" 83 that the power of the President to make treaties (with, significantly, the consent of the Senate) includes the judicial power to interpret and apply them. In a near exact textual parallel with Article II's Vesting Clause, Article III, Section 1 provides that "[t]he judicial Power of the United States, shall be vested in one supreme Court, and in such inferior Courts as the Congress may from time to time ordain and establish." 84 As we have seen, this judicial power expressly extends to treaties as well. ${ }^{85}$

Second, the Supreme Court long ago established that the initial power to create law does not include a subsequent power to interpret it. The Constitution expressly vests in Congress the power to create federal law through Article I legislation (even over the veto of the President). The Supreme Court has nonetheless emphatically declared that this power to create federal law does not by extension grant to a later Congress the authority over its interpretation. Specifically, the Court has concluded that the interpretive opinions of a later Congress form a "hazardous basis" for discerning the meaning of an earlier statute,$^{86}$ and indeed are of "very little, if any, significance. ${ }^{.87}$ Even as the preeminent institution in creating Article I legislation, a subsequent Congress does not have the power to interpret an earlier statute without adhering to the full constitutional process for the creation of binding legal norms (that is, without passing a law signed by, or over the veto of, the President).

82. See Yoo, Politics as Law, supra note 15, at 864 (criticizing the Reagan administration with regard to the first ABM remterpretation controversy because it "fail[ed] to make the stronger argument that the President has the sole constitutional power to reinterpret treaties on behalf of the nation ..."); $i d$. at 878 (asserting that the President has "unilateral authority to reinterpret treaties").

83. Id. at 870 (arguing that "the Treaty Clause's placement in Article 1l, Section $\mathbf{2}$ indicates that the power to make treaties, and by extension to interpret them, remains an executive one").

84. U.S. Const. art. $111, \S 1$.

85. U.S. CoNST. art. 1ll, $\$ 2$, cl. 1. ("The Judicial Power shall extend to ... Treaties made, or which shall be made" under the authority of the United States.).

86. See S. Dakota v. Yankton Sioux Tribe, 522 U.S. 329, 355 (1998) ("We have often observed, however, that 'the views of a subsequent Congress form a hazardous basis for inferring intent of an earlier one."' (quoting United States v. Philadelphia Nat'l Bank, 374 U.S. 321, 348-49 (1963))); see also Pension Benefit Guarantee Corp. v. LTV Corp., 496 U.S. 633, 650 (1990) (same); United States v. Price, 361 U.S. 304, 313 (1960) (same).

87. United States v. Southwestern Cable Co., 392 U.S. 157, 170 (1968) (quoting Rainwater v. United States, 356 U.S. 590, 593 (1958)); see also Cent. Bank of Denver, N.A. v. First lnterstate Bank of Denver, N.A., 511 U.S. 164, 185 (1994) ("[W]e have observed on more than one occasion that the interpretation given by one Congress ... to an earlier statute is of little assistance in discerning the meaning of that statute."(quoting Pub. Employees Ret. Sys. of Ohio v. Betts, 492 U.S. 158, 168 (1989))). 
The observation that the treaty power is found in Article II and not in Article I in this respect is a distinction without a differencc. Like Article I legislation, the result of the cooperation of the executive and legislative branches in the creation of self-executing treaties under Article II is domestically enforceable federal law. Once this occurs, that the President had the initial power to make such a treaty does not mean that he retains the judicial power to interpret and apply it, any more than the Senatc's participation in the process grants it such a power. ${ }^{88}$ While foreign policy concerns may justify some form of calibrated deference to the interpretive views of the executive, ${ }^{89}$ Article III ultimately vests the judicial power over treaties in the federal courts.

In broad purpose, Article III reflects the insight that control by one of the political branches over the power both to create and to apply the law threatens the structural protections of the Constitution. ${ }^{90}$ Indeed, as the Supreme Court observed in Plaut v. Spendthrift Farm, Inc., one of the core purposes of Article III was to abolish the practice, common at the time of the adoption of the Constitution, of state political bodies acting as the final judicial authority on individual cases. ${ }^{91}$ In the case of those treaties that operate as domestically enforceable law, the separation of powers doctrine thus operates to ensure that one political branch (here, the executive) cannot combine its authority to create legal rights and obligations with an unchecked power to interpret and apply them to specific citizens and disputes. $^{92}$

Moreover, the view that the executive has exclusive authority to interpret treaties renders irrelevant the Senate's mandatory participation in the creation of Article II treaty law. If, subsequent to the Senate's advice

88. Like Article 1 legislation, the Supreme Court has held that those involved in the ratification of a treaty do not thereby control its later interpretation. See Fourteen Diamond Rings v. United States, 183 U.S. 176, 180 (1901) ("The mearing of the treaty cannot be controlled by subsequent explanations of some of those who may have voted to ratify it.").

89. See infra Part III.B.

90. See The Federalist No. 47, at 207 (James Madison) (J. Gideon ed., 1831) (warning of the risks of a "despotic government" that accompanies the "accumulation of all powers, legislative, Executive, and judiciary in the same hands"); $i d$. ("[T]he accumulation of all powers, legislative, Executive, and judiciary, in the same hands... may justly be pronounced the very definition of tyranny."); id. at 209 (quoting Montesquieu to the effect that "were the power of judging ... joined to the Executive power, the judge inight behave with all of the violence of an oppressor").

91. See 514 U.S. 211, 217-25 (1995) (describing this purpose of Article 111). More broadly, as Justice Kennedy insightfully observed in Clinton v. City of New York, "[s]eparation of powers was designed to implement a fundamental insight: concentration of power in the hands of a single branch is a threat to liberty." 524 U.S. 417, 450-51 (1998) (Kennedy, J., concurring).

92. When applied to self-executing treaties, Professor Yoo's argument that the President has the exclusive power of interpretation also collapses under its own weight. If the President has such exclusive authority, then presuinably federal courts would not have the authority to even entertain causes of action and resolve disputes nnder such treaties. Alternatively, courts would have to stay all actions founded on treaty rights until the executive branch has instructed the courts regarding the meaning of the relevant provisions. 
and consent to a self-executing treaty, the President has a unilateral, unreviewable power to interpret (and reinterpret) it, the careful cooperation between the executive and legislative branches prescribed by the Constitution becomes meaningless. Presumably, then, any President would have the unilateral authority to disregard the text of a treaty and even express Senate reservations to a treaty's substance and effect. ${ }^{93}$ ln short, contrary to the Constitution's careful safeguards against arbitrary governmental actions, the very content of the law would be subject to the fleeting whims of executive-branch officials.

Ultimately Professor Yoo's position on the interpretive power of the President clashes with the established principle that treaties, if their substance so directs, may create individual rights that are directly enforceable as federal law in federal courts. For such treaties, an assertion that the executive should have exclusive interpretive authority is inconsistent with Article VI's designation of treaties as law, Article III's vesting of flnal judicial power in the federal courts, the Supreme Court's long-standing jurisprudence that self-executing treaties have "the force and effect of a legislative enactment," 94 and the mandatory role of the Senate in creating Article II treaty law.

To be sure, not all self-executing treaties are substantively the same. Some, though enforceable by individuals like legislation, in fact may have attributes that more closely resemble a sovereign contract. These attributes arise, for instance, when nations through a treaty undertake certain sovereign obligations owed directly to individual citizens (either the other nation's or their own) that are nonetheless enforceable by way of a private right of action or defense. Examples here include extradition and taxation treaties..$^{95}$ These attributes of treaties only suggest, however, that different interpretive approaches may be appropriate for different types of treaties, ${ }^{96}$ and that some form of calibrated deference to the interpretive views of the

93. See RESTATEMENT (THIRD) OF Foreign Relations $§ 314$ (1987) (describing the Senate's power to state binding reservations and understandings when giving its consent to a treaty); id. $\S 303$, $\mathrm{cmt}$. $\mathrm{d}$ (stating that "[t]he Senate may ... give its consent on conditions that do not require change in the treaty but relate to its domestic application"); see also Michael J. Glennon, The Constitutional Power of the United States Senate to Condition Its Consent to Treaties, 67 CHI.-Kent L. Rev. 533 (1991) (analyzing this power in greater detail).

94. See Whitney v. Robertson, 124 U.S. 190, 194 (1888); see also supra notes 74-80 and accompanying text (describing this Supreme Court jurisprudence in more detail).

95. See supra notes 1 and 2 (citing extradition and taxation treaties that have been accepted by the United States).

96. See Restatement (Third) of Foreign Relations, supra note 93, $\S 325$, cmt. D. The Restatement states:

Different types of agreements may call for different interpretative approaches.... Agreements involving a single transaction between governments, such as a transfer of territory or a grant of economic assistance should be construed like similar private contracts between private parties. Different approaches to interpretation have developed for particular categories of agreements such as extradition treaties, tax treaties, etc. 
executive may be appropriate even with self-executing treaties. ${ }^{97}$ But in other contexts, the view of treaties as mere contracts regulating the international conduct of sovereigns dissolves almost entirely. Some treaties impose no substantive obligations and involve no performance, whether domestic or international, by sovereign entities at all.

This latter class of treaties was the subject of my argument in Dynamic Treaty Interpretation. ${ }^{98}$ At issue there were a number of selfexecuting private-law conventions (some already ratified by the United States, ${ }^{99}$ others waiting to $\mathrm{be}^{100}$ ) that solely regulate areas of international commercial law. ${ }^{101}$ As 1 noted there, the operative provisions of these treaties impose no substantive obligations on the United States in its international conduct as a sovereign entity. ${ }^{102}$ Rather, their subject is purely the private relations between private actors involved in defined commercial law transactions. Thus, like typical domestic private-law statutes, the substantive provisions of these treaties contemplate enforcement only by private actors and against private actors. ${ }^{103}$ As a result, these conventions, as I argued in Dynamic Treaty Interpretation, might properly be conceived of as "legislative treaties." 104

These self-executing private-law conventions fall squarely within the constitutional contemplation of treaties as equivalent to acts of legislation. ${ }^{105}$ Because they solely regulate private relations, involve no

97. I examine this point in greater detail infra Part III.

98. See generally Van Alstine, supra note I6, at 696-701.

99. The most prominent treaty that the United States ratified is the United Nations Convention on Contracts for the International Sale of Goods. See CISG, supra note 7. For information on this treaty, see infra note 18I. Another example is the United Nations Convention on the Limitation Period in the International Sale of Goods (with 1980 Protocol amending the Convention), which United States ratified in 1994. See Convention on the Linitation Period in the International Sale of Goods, reprinted in 13 I.L.M. 952 (1974); Protocol Amending the Convention, reprinted in I9 I.L.M. 696 (I980).

100. For an examination of these treaties, see infra notes I79-99 and accoinpanying text.

10I. In accordance with an occasional practice, some of the commercial law conventions examined in Dynamic Treaty Interpretation refer to the member states as "contracting states." See, e.g., CISG, supra note 7, art. I(1). This formal designation does not, however, change the substance of such conventions as ones that solely regulate the commercial relations of private entities.

102. See Van Alstine, supra note 16, at 700-01. The conventions also contain certain diplonatic provisions. See, e.g., CISG, supra note 7, arts. 88-10I. But these merely respect procedural formalities for accession, ratification, denunciation, and the like, and impose no substantive obligations on the member states.

I03. See Van Alstine, supra note 16 , at $700-01$.

104. See id. at 705-06; see also id. at 700 (observing that the private-law conventions analyzed there have the "look and feel of standard federal statutes").

105. Professor Yoo has argued that historical references, which distingnish commercial from noncommercial treaties, support a presumption of non-self-execution for noncommercial treaties. See Yoo, Non-Self-Execution, supra note 14, at 2057-58 (citing statements by the "Federal Farmer"). But as with other aspects of the debate on this nnatter, other scholars have pointed to compelling historical evidence to the contrary. See Flaherty, supra note I4, at 2I40 (arguing that "[a]s with the thesis against self-execution generally, [Professor Yoo] offers no convincing evidence that panicky Antifederalists, or the Federalists theinselves, widely adopted an understanding that commercial treaties, much less any treaty falling within Congress's Article I powers, would not function as the supreme law of the land"). 
substantive "contractual" obligations by sovereign actors, and contemplate no discretionary sovereign conduct at all, they address themselves to the judicial, not the political, branches. Moreover, these treaties directly create a federal cause of action that private parties may pursue in federal courts. ${ }^{106}$ Like other forms of domestic law, therefore, the application and interpretation of these legislative treaties falls within the judicial power of the federal courts under Article III of the Constitution.

In short, for those treaties that create rights or obligations that are enforceable as domestic law by or against individuals, the federal courts have the same formal constitutional powers to apply the law as they do with Article I legislation. These powers may include not only interpretation of the meaning of the law, but also the supplemental authority, as delegated to them by those institutions with the constitutional power, to fill in and round out the law within the scope of a treaty. ${ }^{107}$ As we shall see in Part II below, although the federal judiciary may not have inherent developmental powers with regard to all treaties, it may obtain those powers through a deliberate and circumscribed authorization found in specific treaties themselves.

\section{II \\ Treaty Delegation of Developmental Powers}

\section{A. Statutory Delegation}

The premise of the separation of powers doctrine at the core of the Constitution is that dividing governmental powers into separate, sometimes competing, institutions advances the interests of ordered liberty. ${ }^{108}$ This does not mean, of course, that the legislative, executive, and judicial functions exist in hermetically sealed compartments in which each branch solely exercises its own, unique powers. ${ }^{109}$ Rather, the separation of

106. See Asante Techs., Inc. v. PMC-Sierra, Inc., 164 F. Supp. 2d 1142, 1147-52 (2001) (holding that the United Nations Sales Convention ratified by the United States creates a private right of action in federal courts and preempts state law causes of action within its scope (citing Delchi Carrier SpA v. Rotorex Corp., 71 F.3d 1024, 1027-28 (2d Cir. 1995); Filanto, S.P.A. v. Chilewich 1nt'l Corp., 789 F. Supp. 1229, 1237 (S.D.N.Y. 1992))).

107. See infra Part 1I.B.

108. See Clinton v. City of New York, 524 U.S. 417, 450-51 (1998) (Kennedy, J., concurring) (observing that the Framers of the Constitution "used the principles of separation of powers and federalism to secure liberty in the fundamental political sense of the term, quite in addition to the idea of freedom from intrusive governmental acts" protected by the Bill of Rights); Loving v. United States., 517 U.S. 748, 756 (1996) (noting that the framers believed that "freedom is imperiled if the whole of legislative, executive, and judicial power is in the same hands"); Youngstown Sheet and Tube Co. v. Sawyer, 343 U.S. 579, 635 (1952) (Jackson, J., concurring) (observing that "the Constitution diffuses power the better to secure liberty").

109. See Buckley v. Vallejo, 424 U.S. 1, 121 (1976) (per curiam) (observing that the Framers believed that a "hermetic sealing off of the three branches of Government from one another would preclude the establishment of a Nation capable of governing itself effectively"); Thomas W. Merrill, The Common Law Powers of Federal Courts, 52 U. CHI. L. REv. 1, 21 (1985) ("[T] he notion that 
powers doctrine operates within the context of a need for a "workable government." 110 With this in mind, the Supreme Court has long recognized that Congress may delegate to its coordinate branches of government certain decision-Inaking powers that it otherwise could exercise itself. ${ }^{111}$ As the Court explained in Mistretta $v$. United States, ${ }^{112}$ "in our increasingly complex society, replete with ever changing and inore technical problems, Congress simply cannot do its job absent an ability to delegate power under broad directives." 113

The Supreme Court has made clear, however, that Congress may not delegate to nonlegislative bodies the entirety of its legislative powers on a given subject. ${ }^{114}$ Nonetheless, as Justice Scalia has observed, the Supreme Court has "almost never felt qualified to second-guess Congress regarding the permissible degree of policy judgment that can be left to those executing or applying the law." 115 As a result, historically there have been only two instances in which the Supreme Court has found that Congress delegated excessive decision-making authority. ${ }^{116}$

Congress is the exclusive federal lawmaking body is an oversimplification of constitutional realitynot only the reality of today, in which administrative agencies churn out reams of edicts having the force of law, but also the reality presented by the Constitution itself."); Yoo, Politics as Law, supra note 15, at 869 ("Clearly, the Constitution does not establish a pure separation of powers in which each branch solely exercises all functions peculiar to it.").

110. Youngstown Sheet and Tube Co. v. Sawyer, 343 U.S. 579, 635 (1952) (Jackson, J., concurring) (concurring in a conclusion that President Truman exceeded his executive powers by seizing steel mills during the Korean War); see also Morrison v. Olson, 487 U.S. 654, 693-94 (1988) ("[W]e have never held that the Constitution requires that the three branches of Government "operate with absolute independence." (quoting United States v. Nixon, 418 U.S. 683, 707 (1974))).

111. See Loving v. United States, 517 U.S. 748, 758 (1996) (stating that the Court had "established long ago that Congress must be permitted to delegate to others at least some authority that it could exercise itself"); Touby v. United States, 500 U.S. 160, 165 (1991) ("Congress does not violate the Constitution merely because it legislates in broad terms, leaving a certam degree of discretion to executive or judicial actors.").

112. 488 U.S. 361 (1989).

113. Id. at 372 .

114. Whitman v. Ain. Trucking Ass'ns, Inc., 531 U.S. 457, 472 (2001) (observing that because Article 1, Section 1, of the Constitution vests its legislative powers in Congress, it "permits no delegation of those powers" (citing Loving v. United States, 517 U.S. 748, 771 (1996))). Instead, a valid delegation of decision-making authority requires that Congress "lay down by legislative act an intelligible principle to which the person or body authorized to [act] is directed to conform." Id. at 472 (quoting J.W. Hampton, Jr., \& Co. v. United States, 276 U.S. 394, 409 (1928)); see also Mistretta, 488 U.S. at 379 (observing that the nondelegation doctrine requires only that Congress provide sufficient guidance to permit a court "to ascertain whether the will of Congress has been obeyed" (quoting Yakus v. United States, 321 U.S. 414, 425-26 (1944))).

115. Whitman, 531 U.S. at 474 (quoting Mistretta, 488 U.S. at 416 (Scalia, J., dissenting)).

116. See A.L.A. Schechter Poultry Corp. v. United States, 295 U.S. 495 (1935); Panama Refining Co. v. Ryan, 293 U.S. 388 (1935). The Court in Whitman stated:

In the history of the Court we have found the requisite "intelligible principle" lacking in only two statutes, one of which provided literally no guidance for the exercise of discretion, and the other of which conferred authority to regulate the entire econoiny on the basis of no more precise a standard than stimulating the economy by assuring "fair coinpetition."

Whitman, 531 U.S at 474 (citing the Panama Refining and Schechter Poultry cases). 
The traditional recipients of congressional delegations of decisionmaking authority have been executive-branch agencies. This does not necessarily mean that the Constitution also permits the exercise of similar decision-making powers by the federal courts. ${ }^{117}$ Indeed, at least since Erie R.R. v. Tompkins, ${ }^{118}$ the constitutional premise of a federal government of limited, specifically enumerated powers has been understood as also prohibiting federal courts from exercising general common-law-making powers, ${ }^{119}$ except in narrow circumstances. ${ }^{120}$ The result of these federalism concerns is that, unlike their state counterparts, federal courts "do not possess a general power to develop and apply their own rules of decision."121

Like administrative agencies, however, federal courts may obtain the authority to develop the law through a delegation from Congress. For nearly fifty years, the Supreme Court has recognized that within proper limits, Congress may confer on the federal courts the power to develop the law within the scope of a statute in common-law fashion. In other words, although the federal courts do not inherently have such powers, they may exercise decision-making authority when "Congress has given [them] the power to develop substantive law." 122

This power of decision-making authority delegated by Congress traces its formal lineage to the Supreme Court's opinion in Textile Workers

117. See Merrill, supra note 109, at 21 (noting that "the fact that the Constitution permits some sharing of the lawmaking power with the executive branch does not require us to conclude that the Constitution erects a system of shared powers with respect to lawmaking by the federal courts").

118. 304 U.S. 64,78 (1938). There are indications as early as 1834 of a recognition by the Supreme Court that the Constitution places limits on the common-law powers of federal courts. See Wheaton v. Peters, 33 U.S. (8 Pet.) 591, 658 (1834) ("It is clear, there can be no common law of the United States.").

119. See Northwest Airlines, Inc. v. Transp. Workers Union of Am., 45I U.S. 77, 95 (I981) (emphasizing with regard to common-law powers that "the federal lawmaking power is vested in the legislative, not the judicial, branch of government"); see also Merrill, supra note 109, at I3 (explaining on the same issue that "[a]s the general structure of the Constitution and the tenth amendment make clear, the framers anticipated that the federal government would exercise only specifically enumerated powers").

I20. Absent congressional authorization, federal common law is limited to those cases in which there is a "significant conflict between some federal policy or interest and the use of state law." O'Melveny \& Myers v. FDIC, 512 U.S. 79, 87 (I994) (quoting Wallis v. Pan Am. Petroleum Corp., 384 U.S. 63, 68 (1966)); see also Texas Indus. v. Radcliff Materials, Inc., 451 U.S. 630, 641 (1981) (observing that "absent some congressional authorization to formulate substantive rules of decision, federal common law exists only in such narrow areas as those concerned with the rights and obligations of the United States, intcrstate and international disputes implicating the conflicting rights of States or our relations with foreign nations, and admiralty cases").

121. City of Milwaukee v. llinois, 451 U.S. 304, 312 (1981).

122. Texas Indus., 451 U.S. at 640; see also Merrill, supra note 109, at 40 (describing such an authority of the federal courts as "delegated lawmaking" and observing that it "takes place when Congress ... confcr[s] power on the federal courts to fasbion federal mles of decision in order to round out or complete a... statutory scheme"). 
Union v. Lincoln Mills. ${ }^{123}$ Decided in the shadow of Erie R.R. v. Tompkins, the Court in Lincoln Mills faced an absence of congressional guidance in the Labor Manageinent Relations Act ${ }^{124}$ on the proper enforcement of collective bargaining agreements. After examining the Act's legislative history, the Court found that a single provision, Section 304(a), reflected an implied congressional determination to "authorize[] federal courts to fashion a body of federal law" regarding the enforceinent of such agreements. ${ }^{125}$ Although some have questioned the factual foundation for this speciflc conclusion, ${ }^{126}$ the decision in Lincoln Mills confirmed that Congress has the power to delegate to the federal courts the authority to develop the law within the scope of a legislative enactment. ${ }^{127}$

Contrary to Professor Yoo's suggestion in his Rejoinder to this Essay, Lincoln Mills is not an isolated anomaly. ${ }^{128}$ Since that case, federal courts have found on a number of occasions that Congress either expressly or impliedly ${ }^{129}$ delegated authority to the federal courts to develop the law within the scope of a statute. The most prominent example of express delegation may be Rule 501 of the Federal Rules of Evidence, which addresses the issue of testimonial privilege. ${ }^{130}$ In spite of the policy-laden nature of this issue, in Rule 501, unlike in other provisions in the Federal Rules, Congress simply instructed that such privileges are to be "governed by the principles of the common law as they may be interpreted by the courts of the United States in the light of reason and experience." "131 Instead of undertaking a detailed legislative prescription, therefore, Congress expressly conferred on the federal courts the power to develop the law in this area in a common-law fashion. ${ }^{132}$

123. 353 U.S. 448 (1957).

124. 29 U.S.C. $§ 185(a)(1947)$.

125. Lincoln Mills, 353 U.S. at 451.

126. Justice Frankfurter, for example, strongly objected in his dissent in Lincoln Mills to the majority's reliance on the limited legislative history of the Labor Management Relations Act to support its conclusion. See id. at 460-64 (Frankfurter, J., dissenting).

127. See also Merrill, supra note 109, at $40-41$ (concluding that Lincoln Mills "is generally taken to have established the principle that it is within the power of Congress to delegate lawmaking power to the federal courts"); Martha A. Field, Sources of Law: The Scope of Federal Common Law, 99 HaRv. L. REv. 883, 893-99 (1986) (describing the foundations for the exercise of common-law powers by federal courts).

128. See John Yoo, Treaty Interpretation and the False Sirens of Delegation, 90 CALIF. L. Rev. 1305,1329 (2002).

129. See Merrill, supra note 109 , at 42 (observing with regard to the common-law powers of federal courts that "[d]lelegated powers of lawmaking can be either express or implied"). I discuss these instances of congressional delegation to the courts infra notes 130-38 and accoinpanying text.

130. See FED. R. Evid. 501.

131. Id. See also Merrill, supra note 109, at 42 (observing that the "intent to delegate [im Rule 501] is unmistakable"); Tramınel v. United States, 445 U.S. 40,47 (1980) (noting that in the drafting of Rule 501 Congress rejected a inore detailed proposal in favor of Rule 501's general mandate to federal courts to develop the law based on common-law principles).

132. See Jaffee v. Redmond, 518 U.S. 1, 8-9 (1996) (noting the instruction in Rule 501 that courts are to develop testimonial privileges based on common-law principles and stating that the rule "did not 
The Sherman Anti-Trust Act provides the paradigmatic example of an implied delegation of common-law-making powers. ${ }^{133}$ Given the broad language in Sections One and Two of that Act, ${ }^{134}$ the Supreme Court has often found that Congress in effect delegated to the federal courts the authority to develop the law within the Act's scope "by drawing on common-law tradition." 135 Even Justice Scalia has acknowledged that the broad "restraint of trade" term in the Sherman Act contemplates a "dynamic" development of the law by the courts, one that "imvokes the common law itself." 136 Other instances properly viewed as implied delegations of decision-making authority include Section 10(b) of the Securities Exchange Act of $1934^{137}$ and the fiduciary responsibility provisions of the Employee Retirement lncome Security Act. ${ }^{138}$

freeze the law governing the privileges of witnesses in federal trials at a particular point in our history, but rather directed federal courts to "continue the evolutionary development of testimonial privileges"” (quoting Trammel v. United States, 445 U.S. 40, 47 (1980))).

133. See 15 U.S.C. $\$ 1(2000)$.

134. See 15 U.S.C. $\$ \S 1-2(2000)$.

135. Nat'l Soc'y of Prof'l Eng'rs v. United States, 435 U.S. 679, 688 (1978). For more detailed examinations of the implied delegation of lawmaking authority in the Sherman Act, see Merrill, supra note 109, at 44-46; William F. Baxter, Separation of Posvers, Prosecutorial Discretion, and the "Common Law" Nature of Antitrust Law, 60 TEx. L. REv. 661, 662-73 (1982); Frank H. Easterbrook, Is There a Ratchet in Antitrust Law?, 60 TEx. L. REv. 705, 706 (1982); see also Sunstein, supra note 18, at 421 (observing that the Supreme Court has interpreted the Sherman Act "as a delegation of policymaking power pursuant to quite open-ended criteria").

136. Bus. Elecs. Corp. v. Sharp Elecs. Corp., 485 U.S. 717, 732 (1988) ("The Sherman Act adopted the term 'restraint of trade' along with its dynamic potential. It invokes the common law itself, and not merely the static content that the common law had assigned to the term in 1890."); see also State Oil Co. v. Khan, 522 U.S. 3, 20-21 (1997) (observing that "the general presumption that legislative changes should be left to Congress has less force with respect to the Sherman Act in light of the accepted view that Congress 'expected the courts to give shape to the statute's broad mandate by drawing on common-law tradition"' (quoting Nat'l Soc'y of Prof'l Eng 'rs, 435 U.S. at 688)).

137. 15 U.S.C. $\$ 78 \mathrm{j}(\mathrm{b})(2001)$. In Blue Chip Stamps v. Manor Drugstores, the Court declared: When we deal with private actions under rule $10 \mathrm{~b}-5$, we deal with a judicial oak which has grown from little inore than a legislative acorn. Such growth may be quite consistent with the Congressional enactment and with the role of the federal judiciary in interpreting it ... but it would be disingenuous to suggest that either Congress in 1934 or the Securities and Exchange Coinmission in 1942 foreordained the present state of the law with respect to Rule $10 \mathrm{~b}-5$.

421 U.S. 723, 737 (1975). Cf. Musick, Peeler \& Garrett v. Employers Ins. of Wausau, 508 U.S. 286, 293-98 (1993) (holding that the formulation of the contours of Rule 10b-5 actions is a "task ... [that] Congress has left to us" and that the goal in exercising that authority is to determine how Congress would have resolved the particular issue in dispute). See also Merrill, supra note 109, at $45 \mathrm{n.198}$ (observing that "[a]nother prominent example of implied delegated lawmaking is the jurisprudence of 'deceptive and manipulative' practices that has emerged under section 10(b) of the Securities Exchange Act of 1934").

138. 29 U.S.C. $\$ \S 1101-14$ (Supp. V 1999) ("ERISA"); see also Firestone Tire \& Rubber Co. v. Bruch, 489 U.S. 101, 110-11 (1989) (observing that in light of the text and legislative history of ERISA, "we have held that courts are to develop a "federal common law of rights and obligations under ERISA-regulated plans"' (quoting Pilot Life Ins. Co. v. Dedeaux, 481 U.S. 4l, 56 (1987))). Another example of delegated authority to create federal common law is the Federal Employers' Liability Act ("FELA"). See Consol. Rail Corp. v. Gottshall, 512 U.S. 532, 558 (1994) (Souter, J., concurring) (observing that the duty of federal courts "in interpreting FELA ... is to develop a federal common law 
Indeed, sound arguments support a presumption of implied delegated authority whenever Congress legislates in the form of broad standards. ${ }^{139}$ As the Supreine Court observed in Touby v. United States, ${ }^{140}$ "Congress does not violate the Constitution merely because it legislates in broad terms, leaving a certain degree of discretion to... judicial actors."141 Commentators have argued on this basis that Title VII of the Civil Rights Act of $1964^{142}$ and Section $1983^{143}$ likewise reflect instances of congressional delegation of decision-making authority to the federal courts. ${ }^{144}$

Not all statutes, of course, bestow common-law powers on the federal courts, nor may Congress delegate the entirety of its legislative power on a given subject to the federal courts. In parallel with the restrictions of the nondelegation doctrine for other institutions, ${ }^{143}$ a purported statutory

of negligence ... informed by reference to the evolving coininon law"). $C f$. Metro-North Commuter R.R. Co. v. Buckley, 521 U.S. 424, 429 (1997) (citing this observation of Justice Souter).

139. Northwest Airlines, Inc. v. Transp. Workers Union of Am., 451 U.S. 77, 95 (1981) ("Broadly worded... statutory provisions necessarily have been given concrete meaning and application by a process of case-by-case judicial decision in the common law tradition."); McNally v. United States, 483 U.S. 350, 373 (1987) (Stevens, J. dissenting) ("The wide open spaces in statutes such as [The Sherman Act, The Civil Rights Acts, and the inail fraud statute] are inost appropriately interpreted as implicit delegations of authority to the courts to fill in the gaps in the common-law tradition of case-by-case adjudication."); see also Merrill, supra note 109, at 43-46 (arguing that when Congress legislates broad legal standards or adopts a legal standard that is borrowed from the common law, there are "rebuttable presunptions" of delegated lawmaking). In some cases, it nay be very difficult to determine where "interpretation" in the narrow sense of determining intended nueaning ends and where the developinent of the law in accordance with delegated authority begins. Interestingly, the Supreme Court recently has recognized a sort of iniddle ground for soine statutory schemes, in which courts nust apply "federal law," but apparently not a form the court wishes to identify as "federal common law." See Burlington Indus., Inc. v. Ellerth, 524 U.S. 742, 754-55 (1998) (holding that "Congress has directed federal courts to interpret Title VII based on agency primciples," but stating that "[t]his is not federal common law in 'the strictest sense, i.e., a rule of decision that amounts, not simply to an interpretation of a federal statute, but rather, to the judicial 'creation' of a special federal rule of decision'" (quoting Atherton v. FDIC, 519 U.S. 213, 218 (1997))); see also Paul Lund, The Decline of Federal Common Law, 76 B.U. L. REv. 895 (1996) (discussing the new class of federal law in which federal courts refer to state common law even when formal federal cominon law does not govern a particular case).

140. 500 U.S. 160 (1991).

141. Id. at 165 .

142. See J. Hoult Verkerke, Note, Compensating Victims of Preferential Employment Discrimination Remedies, 98 YALE L.J. 1479, 1491 (1989) (stating that "Congress affirmatively dclegated to federal courts the task of developing an equitable system of reniedies" under Title VII); see also Holder v. Hall, 512 U.S. 874, 966 (1994) (Stevens, J., concurring) (arguing that in both Title VII and the Sherman Act "Congress has legislated in general terms," and that both Acts thus require the courts to formulate their own theories of implementation).

143. 42 U.S.C. $\$ 1983$ (Supp. V 1999).

144. See Kit Kimports, The Buck Does Not Stop Here: Supervisory Liability in Section 1983 Cases, 1997 U. ILL. L. REv. 147, 157 (arguing that "Congress delegated to the federal courts the task of developing the law" under Section 1983); Jack M. Beermann, A Critical Approach to Section 1983 with Special Attention to Sources of Low, 42 STAN. L. REv. 51, 88 \& n.197 (1989) (arguing that Congress has delegated to the federal courts "broad discretion in interpretation" under Section 1983).

145. This is particularly true of administrative agencies. See supra note 114 and accoinpanying text (citing Supreme Court authority to the effect that when delegating legislative powers Congress inust establish an "intelligible primciple" to guide the discretion of administrative agencies); see also 
delegation must both reflect a congressional intent to confer developmental authority and reasonably mark out the boundaries within which the courts may exercise their discretion. ${ }^{146}$ As Professor Thomas Merrill has correctly observed, if such a delegation satisfies these criteria, "it does not violate [constitutional] principles of federalism, separation of powers, or electoral accountability."147

\section{B. Treaty Delegation}

While there is no constitutional infirmity in a deliberate and circumscribed congressional delegation to the federal courts of a power to develop the law within the scope of a statute, a question emerges whether similar delegation may occur through treaties. Professor Yoo suggests that the issues are separate and doubts the constitutional foundation for such a delegation of power in the treaty context. ${ }^{148}$ The short response to this challenge is that, like delegations under Article I statutes, the source of the enhanced federal-court interpretive authority under treaties is the constitutionally empowered "treaty-lawmakers" themselves: the President and a supermajority of the Senate. In other words, the power to develop the law within the scope of a treaty arises not from an arrogation of authority by the courts, but rather from a circumscribed delegation by those with the constitutional power to create federal law through the vehicle of a treaty.

From a formal perspective, the Constitution establishes that selfexecuting treaties have the same domestic force and effect as Article I legislation. ${ }^{149}$ The inclusion of treaties within the judicial power of federal courts in Article IIl likewise places them on an equal footing with legislative law. To be sure, the treaty-lawmakers retain the power to direct through the substance of a treaty that it will not at all create domestic law without implementing legislation by Congress. ${ }^{150}$ But when they choose to

United States v. Chicago, Milwaukee, St. Paul \& Pacific R.R. Co., 282 U.S. 311,324 (1931) ("Congress cannot delegate any part of its legislative power except under the limitation of a prescribed standard ....").

146. See Merrill, supra note 109, at 41 (arguing, compellingly in my view, that Congress may delegate lawmaking authority to the courts if "the delegation is specifically intended and the area of delegation is reasonably circumscribed").

147. Id. As Professor Merrill also suggests, for reasons of electoral accountability and the absence of judicial review, it may be appropriate for Congress to give more guidance to the courts than administrative agencies. Id. at $4 \mathrm{I} \mathrm{n.I82} \mathrm{(noting} \mathrm{also} \mathrm{that} \mathrm{"[i]t} \mathrm{may} \mathrm{also} \mathrm{be} \mathrm{that} \mathrm{the} \mathrm{test} \mathrm{for} \mathrm{assessing}$ delegations to the executive branch is simply too lax"). This observation does not alter, however, the fundamental point that Congress has the power to delegate a circumscribed decision-making authority to the federal courts.

148. See Yoo, Politics as Law, supra note 15, at $879 \mathrm{n} .85$ (arguing that the delegation argument advanced in Dynamic Treaty Interpretation "suffers from [a] failure to identify any constitutional authorization for such an enormous transfer of power from the treatymakers to the courts").

149. See supra notes $74-80$ and accompanying text.

150. See supra notes 63-68 and accompanying text (discussing the various reason why treatics may not be self-executing); see also Foster v. Neilson, 27 U.S. 253, 314 (1829) (when a treaty is in the 
adopt self-executing treaties which create rights or obligations enforceable by individuals, the coinbined effect of Article VI and Article III is that the formal judicial power in relationship to the treaty is the same as that to Article I legislation. ${ }^{151}$ For this reason, the Supreme Court has declared that treaties are "equivalent to [acts] of the legislature,"152 that they have the "force and effect of ... legislative enactment[s],"153 and that they "partake of the nature of municipal law... in the same category as other laws of Congress." 154

The formal judicial authority with regard to application and interpretation of self-executing treaties likewise is fundamentally the same as it is with Article I legislation. Even at some of the earliest moments of our constitutional history, some of the Founders expressly acknowledged that the courts were responsible for interpretation of such treaties, just as they were with statutes. For example, Alexander Hamilton observed in Federalist No. 22, "The treaties of the United States, as far as respects individuals, must like all other laws, be ascertained by judicial determinations."155 The Supreine Court also early on confirmed that it possessed the final responsibility for the interpretation of treaties. ${ }^{156}$ In fulfillment of the directive in Marbury v. Madison that the judicial responsibility to apply the law includes the power to "expound and interpret" the law, ${ }^{157}$ the Supreme Court

nature of a mere contract addressed "to the political, not the judicial department ... the legislature must execute the contract before it can become a rule for the Court"); Vazquez, Four Doctrines, supra note 60, at 702 (observing that the Supreme Court's holding in Foster v. Neilson "recognize[d] that the general rule established by the Supremacy Clause, under which treaties are enforceable in the courts without prior legislative action, is one that may be altered by the parties to the treaty through the treaty itself').

151. This does not mean that the deference accorded the lawmakers under treaties and statutes in all cases must be the same. For prudential reasons, courts may properly give deference to the view of the executive in the application and interpretation of some treaties. As I explain below, however, this deference is not an unthinking, absolute one, but rather must be calibrated to the nature of the specific treaty at issue. See infra notes $223-42$ and accompanying text.

152. Foster, 27 U.S. at 314.

153. Whituey v. Robertson, 124 U.S. 190, 194 (1888).

154. The Head Money Cases, 112 U.S. 580, 598 (1884).

155. The Federalist No. 22, at 150 (Alexander Hamilton) (Clinton Rossiter ed., 1961). A similar observation was made by an opponent of the broad power of the judiciary over treaties. "Brutus" criticized the inclusion of treaties as "the law of the land" because "every person who have rights or privileges secured by treaty, will have aid of the courts of law, in recovering them." See "Brutus XIII", in New York JouRnal, 21 February, 1788, reprinted in 16 The DocumentaRY History of THE RatifiCatIon OF THE CONSTITUTION 172 (John P. Kaminski \& Gaspare J. Saladino eds., 1986). I cite these quotations only for purposes of background to the Supreme Court doctrine in the discussion to follow. As I have noted above, the historical background to the treaty power already has been examined exhaustively, and at best mconclusively, by Professor Yoo, and his arguments im turn have been challenged in equal detail by other scholars. See supra note 69 (citing the authority on this historical debate).

156. See, e.g., Fairfax's Devisee v. Hunter's Lessee, 11 U.S. (7 Cranch) 603, 620-27 (1813) (holding that it had the final authority to determme whether state law violated the terms of a treaty); Ware v. Hylton, 3 U.S. (3 Dall.) 199, 283 (1796).

157. 5 U.S. (1 Cranch) 137, 177 (1803). 
has explicitly found that it has the constitutional authority to interpret treaties. ${ }^{158}$

The Court's first major treaty decision, Ware v. Hylton, ${ }^{159}$ provides a good example. The case addressed the effect of the Supremacy Clause on state laws that were contrary to the terms of the 1783 Treaty of Peace with Great Britain. The fourth article of that treaty provided that private creditors "shall meet with no lawful impediment to the recovery of . . debts." 160 Justice Chase, who offered the most detailed opinion on the effect of the Supremacy Clause, found that if an individual creditor "prosecuted his just right, it could only be in a court of justice, and if any [state laws] were set up as a lawful inpediment, the courts were bound to decide, whether this article of the treaty nullified the laws ...."161 With regard to the imterpretive authority of the judiciary, Justice Chase then concluded that "the courts, in which the cases arose, were the only proper authority to decide, whether the case was within this article of the treaty, and the operation and effect of it." 162

For those treaty provisions that create rights enforceable by individuals, then, the federal courts have the same formal constitutional power to apply and interpret the law as they do with Article I statutes. ${ }^{163}$ As we have seen in the statutory context, within proper limits, ${ }^{164}$ the constitutional institutions with the authority to create Article I federal law (the Congress either with the cooperation, or over the veto, of the President) have the power to delegate to the federal courts the authority to develop the substantive law within the scope of a statute. Just as with the formally equivalent creation of Article I federal law, the treaty-lawmakers should have the power to delegate enhanced interpretive powers to the federal judiciary. ${ }^{165}$

158. See, e.g., Japan Whaling Ass'n v. Am. Cetacean Soc'y, 478 U.S. 221, 230 (1986) (holding that "the courts have the authority to construe treaties" (citing Baker v. Carr, 369 U.S. 1986 (1969))).

159. 3 U.S. (3 Dall.) 199 (1796).

160. The Definitive Treaty of Peace Between His Britannic Majesty and the United States of Ainerica, Sept. 3, 1783, U.S.-Gr. Brit., art. 4, reprinted in 2 TREATIES AND OTHER INTERNATIONAL ACTS OF THE UNITED STATES OF AMERICA, 1776-1818, at 151, 154 (Hunter Miller, ed., 1931).

161. Ware, 3 U.S. at 239.

162. Id.

163. Even the Rules of Decision Act makes clear that treaty law, like acts of Congress, can "require or provide" rules of decision that displace state substantive law. See 28 U.S.C. $§ 1652$ (2001) ("The laws of the several states, except where the Constitution or treaties of the United States or Acts of Congress otherwise require or provide, shail be regarded as rules of decision in civil actions in the courts of the United States, in cases where they apply."). But see Mason v. United States, 260 U.S. 545, 559 (1923) (concluding that the Rules of Decision Act is "Inerely declarative of the rule which would cxist in the absence of the statute"). See also Strother v. Lucas, 37 U.S. 410, 439 (1838) ("Treaties are the law of the land, and a rule of decision in all courts.").

164. See supra notes $122-47$ and accompanying text.

165. See also Field, supra note 127, at 889 (arguing that "the process and standards for making federal coinmon law are the same when a treaty ... is the source of authority"); Louis HeNKIN, FOREIGN AFFAIRS AND THE CONSTITUTION 470 n.83 (2d ed. 1996) (concluding that "[i]t has been assumed that constitutional limitations on delegation of legislative power apply as well to delegation by 
But they may do so only within the confines of the separation of powers, federalism, and political accountability concerns that have animated the Supreme Court's nondelegation jurisprudence for statutory delegations. ${ }^{166}$

In the treaty context, these constraints will require that the exercise of decision-nıaking authority by the courts likewise proceed from an intentional and circumscribed delegation of authority by the constitutional institutions empowered to create federal law through the vehicle of a treaty (the President, with the consent of a supermajority of the Senate). ${ }^{167}$ Save for those questions of uniquely national interest, ${ }^{168}$ federal courts will not have common-law developmental powers under a treaty of their own accord, ${ }^{169}$ even on matters with international connections. But if the treaty-lawmakers both intend a delegation and reasonably frame its limits, then the exercise of such powers by the federal courts will originate only froin a deliberate authorization by electorally accountable institutions. These constraints will also ensure, as in the parallel statutory context, that the exercise of delegated authority does not represent an unconstitutional arrogation by federal courts of powers allocated to the other branches of government.

Indeed, the concerns about the delegation of common-law powers to federal courts nay be even less convincing in the treaty context. The principal concern that spawned the Erie limitation on the common-law powers of federal courts was one of federalisin. ${ }^{170}$ In contrast to most areas of Article I legislation, however, the power to create treaties is exclusively a federal one, for the Constitution expressly forbids states from creating law by that mcans. ${ }^{171}$ And, although the issue recently has becoine more controversial, ${ }^{172}$ the Supreme Court has long held that the treaty power granted to the federal government by the Constitution is plenary in scope,

treaty"); Golove, supra note 13, at $1286 \mathrm{n.717}$ (asserting that "treaties are alternative modes of promulgating laws and, hence, ought presumptively to be subject to the same restrictions on delegations to which the identical laws would be subject").

166. See supra notes $145-47$ and accompanying text (describing the limitations on statutory delegation).

167. See id. (describing these limitations); see also Merrill, supra note 109, at 19-24 (describing the separation of powers limitations on federal common law).

168. An example is core inatters of international relations, such as the Act of State Doctrine. See Banco Nacional de Cuba v. Sabbatino, 376 U.S. 398, 423-27 (1964) (holding that federal common law in this area is "necessary to protect uniquely federal interests").

169. See Bradford R. Clark, Separation of Powers as a Safeguard of Federalism, 79 TEx. L. REv. $1321,1412-19$ (2001) (observing that the limitations on federal common law reflect the idea that "the Constitution constrains ... the inanner in which the federal government may exercise [its delegated] powers to displace state law"); Merrill, supra note 109, at 13-19 (describing the federalisin limitations on federal common law).

170. See Merrill, supra note 109 , at 13 (observing that federalism "was the key principle invoked in Erie Railroad v. Tompkins").

171. See U.S. CoNST. art. $1, \S 10$ (providing that "[n]o State shall enter into any Treaty, Alliance, or Confederation").

172. See supra note 13 and accompanying text (describing the controversy over whether there are any substantive limits on the scope of the treaty power). 
subject only to the more specific constitutional protections such as those found in the Bill of Rights. ${ }^{173}$ But within these (admittedly important) constraints, a delegation of authority to develop the law under a treaty does not violate the federalism principles that limit the common-law powers of federal courts.

The only Supreme Court opinion that has directly addressed this issue fully comports with this reasoning. In Zicherman v. Korean Airlines, Co. ${ }^{174}$ an opinion authored by Justice Scalia, the Court addressed how it should fill a particular regulatory gap in the Warsaw Convention on air transportation. ${ }^{175}$ It ultimately decided that resolution of this issue required the Court to apply otherwise-applicable domestic law. ${ }^{176}$ But it only did so after finding as a factual matter that the treaty did not "empower [the Court] to develop some common-law rule-under cover of general admiralty law or otherwise-that will supersede the normal federal disposition."177 That is, the Court did not question that the treatylawmakers have the authority to empower federal courts to develop the law under a treaty; it merely held that they factually had not done so in that case. ${ }^{178}$

In contrast to the treaty at issue in Zicherman, the private-law conventions I analyzed in Dynamic Treaty Interpretation expressly empower the courts to develop federal common law. ${ }^{179}$ Specifically, I examined the interpretive principles expressly prescribed in the United Nations Convention on Contracts for the International Sale of Goods, ${ }^{180}$ a

173. See Missouri v. Holland, 252 U.S. 416 (1920) (holding that the federal government could exercise by treaty even powers that are denied Congress under Article 1, Section 8 of the Constitution); see also Golove, supra note 13, at 1257-66 (describing Missouri v. Holland in more detail and defending its conclusion); Reid v. Covert, 354 U.S. 1, 16-18 (1957) (holding that a treaty may not contravene specific provisions of the Constitution).

174. 516 U.S. 217 (1996).

175. Id. at 218-19.

176. Id. at $226-28$.

177. Id. at 229. Subsequent federal courts decisions have followed Zicherman without expressly addressing whether a treaty inay delegate lawinaking authority. See lns. Co. of N. Am. v. Fed. Express Corp., 189 F.3d 914, 920-21 (9th Cir. 1999) (citing Zicherman as support for a decision to "refrain from fashioning a federal common law meaning to the term willful misconduct" under the Warsaw Convention); Pescatore v. Pan Am. World Airways, Inc., 97 F.3d 1, 9 (2d Cir. 1996) (refusing to fill a gap in the Warsaw Convention because it "does not authorize federal common law").

178. Zicherman, 516 U.S. at 229.

179. Even at the time of the submittal of this treaty to the Senate for its advice and consent, it was the clear understanding of the executive branch that the courts would apply the U.N. Sales Convention. See Letter of Transmittal from the President of the United States to the Senate With Legal Analysis of the United Nations Convention on Contracts for the International Sale of Goods, Sept. 21, 1983, SEN. TREATY Doc. No. 98-9, reprinted in 22 I.L.M. 1368, 1369 (1983) (containing a statement by the secretary of state that "[t]he Convention ... is self-executing and thus requires no federal implementing legislation to come into force throughout the United States"); id. at 1371 (referring to the application of the Convention "by American courts").

180. See CISG, supra note 7. The official, English-language version is also reprinted at 52 FED. REG. 6264 (1987). 
self-executing treaty ratified by the United States in $1986 .{ }^{181}$ As I explained there, Article 7(2) of that treaty, which has since becoine the paradigm for other, yet unratified treaties, ${ }^{182}$ expressly authorizes the courts to fill gaps that arise in its regulatory scheme. ${ }^{183}$ Specifically, Article $7(2)$ provides that "[q]uestions ... not expressly settled" in the Convention "are to be settled in conformity with the general principles on which it is based."184 Neither the treaty itself nor its drafting history identifies these "general principles," however. ${ }^{185}$ Thus, the delegation of the power to fill gaps in the treaty as they emerge over time necessarily contemplates an active role by the courts in the development of the law. ${ }^{186}$

181. The U.S. Senate gave its consent to the U.N. Sales Convention in accordance with Article II, Section 2 in October, 1986, and the United States deposited the ratification with the United Nations Commission on International Trade Law ("UNCITRAL") on December 11 th of the same year. For more details on the history of the ratification of this treaty, see Peter Wimship, Congress and the 1980 International Sales Convention, 16 GA. J. INT'L AND CoMP. L. 707, 708-10 (1986). The U.N. Sales Convention entered into effect im accordance with its terms on January 1,1988, upon the ratification by ten nations. See CISG, supra note 7, art. 99(1). A complete list of the present member states to the U.N. Sales Convention is published periodically by UNCITRAL. Status of Conventions, available at http://www.uncitral.org/en-index.htm (last visited May 1, 2002).

182. See UNIDROIT Convention on Agency in the International Sale of Goods, Feb. 17, 1983, reprinted in 22 I.L.M. 249 ("Convention on Agency"); UNIDROIT Convention on International Financial Leasing, May 28, 1988, reprinted in 27 l.L.M. 931 ("Convention on Financial Leasing"); UNIDROIT Convention on International Factoring, May 28, 1988, reprinted in 27 I.L.M. 943 ("Convention on Factoring"); UNIDROIT Convention on International Interests in Mobile Equipment, reprinted in 39 I.L.M. 966 (2000) ("Convention on Security Interests"). For more information on these and other UNIDROIT conventions, see the UNIDROIT homepage at http://www.unidroit.org. See also United Nations Convention on International Bills of Exchange and International Promissory Notes, Dec. 9, 1988, reprinted in 28 I.L.M. 170; United Nations Convention on Independent Guarantees and Stand-by Letters of Credit, Dec. 1I, 1995, reprinted in 35 I.L.M. 735. Information on these and the other projects of UNCITRAL can be found on the UNCITRAL homepage, ltttp://www.un.or.at/uncitral/ (last visited May 1, 2002).

183. See Van Alstine, supra note 16, at 733-34.

184. See CISG, supra note 7, art. 7(2). See also Convention on Financial Leasing, supra note 182, art. 6(2); Convention on Factoring, supra note I82, art. 4(2); Convention on Agency, supra note 182, art. 6(2); Convention on Security Interests, supra note I82, art. 6(2).

185. I will not reexamine in detail here the specific means by which the general-principles methodology functions both to fill gaps (both "open" and "hidden") in a treaty and to otherwise permit a dynamic interpretation of the law within the scope of the U.N. Sales Convention. This more detailed analysis can be found in Van Alstine, supra note 16, at 761-91. Article 7(2) permits a court to resort to domestic law only if an active search for the relevant general principles under the treaty yields no results. But see id. at 791 (arguing that because of a separate instruction to interpreters to advance interests of international uniformity, courts should only rarely resort to this provision and apply domestic law).

186. Separately, the general-principles methodology also addresses the debate over the propriety of strict textualist approaches to matters of interpretation. As I explained in Dynamic Treaty Interpretation, a requirement that interpreters probe undefmed general principles in matters of interpretation contemplates enhanced consideration of the drafting history of the Convention. See Van Alstine, supra note 16, at 743-53. Moreover, as was the case with the U.N. Sales Convention, the institutional process for the drafting of most multilateral private-law conventions involves the creation of detailed records of the drafting process, records that are available long before Senate consideration of the treaty. Indeed, the President emphasized the availability of drafting records in recommending the Senate's consent to the U.N. Sales Convention. See Letter of Submittal from George P. Schultz to 
As I argued in Dynamic Treaty Interpretation, by consenting to and ratifying this general-principles inethodology, the Senate and President act through their joint power as constitutional treaty-lawmakers to give "the courts the power to develop substantive law." 187 This delegation through the vehicle of a treaty thus parallels the express statutory delegation of authority in Rule 501 of the Federal Rules of Evidence, and the implied delegations sanctioned by the Supreme Court for the Sherman Anti-Trust Act, Section 301(a) of the Labor Management Relations Act, and other legislative enactments. ${ }^{188}$ Moreover, the Convention carefully marks out the boundaries within which courts nay exercise their discretion. This specific delegation of developmental powers to the federal courts satisfies federalism and separation of powers concerns that limit federal common law by defining its sphere of application ${ }^{189}$ and expressly instructing that the delegated authority to fill regulatory gaps only extends to those matters within that scope. ${ }^{190}$ In addition, the exercise of this delegated authority may only proceed on the basis of the "general principles" reflected in the substance of the treaty adopted by the treaty-lawmakers themselves.

As in the statutory context, a delegation of decision-making authority under a treaty also may occur in an implied fashion. The U.N. Sales Convention, for example, also contains (beyond its express delegation) a number of broad, indefinite terms, ${ }^{191}$ which by their very nature involve the exercise of judicial discretion as they are applied and given functional content over time. ${ }^{192}$ Moreover, an implied authorization to develop federal

Ronald Reagan, Aug. 30, 1983, reprinted in 22 1.L.M. 1368, 1369 (1983) (emphasizing that "[t]he legislative history of the Convention is readily available in English"); Message from the President Transmitting the United Nations Convention on Contracts for the International Sale of Goods, reprinted in 22 I.L.M. 1368 (1983) (same).

187. See Van Alstine, supra note 16, at 756 (quoting Texas 1ndus., Inc. v. Radcliff Materials, lnc., 451 U.S. 630, 640 (1981)); see also Arthur Rosett, Critical Reflections on the United Nations Conventions on Contracts for the International Sale of Goods, 45 Oнго ST. L.J. 265, 299 (1984) (concluding that CISG "[a]rticle 7 seems to express the wish that the broad terms of the Convention be filled in over time by a world common law, a shared body of interpretation that would supply a gloss on the text," but lamenting a supposed absence of sufficient express guidance for the process).

188. See supra notes $123-38$ and accompanying text.

189. See CISG, supra note 7, art. 1 (stating that the Convention applies to sale-of-goods transactions that satisfy certain internationality requirements); see also id. art. 2 (excluding certain classes of transactions that otherwise would fall within the scope of the Convention).

190. See id. art. 7(2) (providing that the authority to fill gaps only extends to matters "governed by the Convention"). Even for matters within the scope of the Convention, examination of text, context, and drafting history may reveal an affirmative decision by the treatymakers to reject a particular normative solution for an ostensibly unresolved issue. For more on this point, see Van Alstine, supra note 16 , at $767-68$.

191. An illustration of this point under the U.N. Sales Convention is the concept of "reasonableness." In over thirty separate provisions, the Convention defines rights or obligations with reference to what is "reasonable" or "unreasonable," but it nowhere defines those terms. For more on this point, see Van Alstine, supra note 16, at 751-52.

192. See supra notes $139-44$ and accompanying text (discussing the implied delegation of decision-making authority that arises when Congress legislates in the form of broad standards). 
common law may flow from a direction to the courts to ensure uniformity in the application of a treaty. ${ }^{193}$ While general interests of federal uniformity alone may be imsufficient, ${ }^{194}$ an instruction from the constitutional lawmakers to the same effect (such as the one set forth in a separate provision of the U.N. Sales Convention and its progeny) ${ }^{195}$ should be viewed as an explicit authorization to develop federal common law to ensure national uniformity for interpretive matters within the scope of a treaty. ${ }^{196}$

As Dynamic Treaty Interpretation argued, such an instruction to promote uniformity also implies that federal courts must consider interpretive court opinions in other member states. ${ }^{197}$ This does not create separate constitutional concerns, however. ${ }^{198} \mathrm{~A}$ decision to afford mandatory precedential effect to foreign court opinions may present an issue worthy of more detailed analysis. But a simple instruction that courts in this country should give appropriate deference to other member-state court opinions in the interests of uniformity merely makes express what the Supreme Court already has found to be a prudential consideration in matters of treaty interpretation. ${ }^{199}$

193. Cf. United States v. Kimbell Foods, Inc., 440 U.S. 715, 728 (1979) (observing that those federal programs that "'by their nature are and must be uniform in character throughout the Nation" necessitate formulation of controlling federal rules" (quoting United States v. Yazell, 383 U.S. 341, 354 (1966))).

194. See O'Melveny \& Myers v. FDIC, 512 U.S. 79, 88 (1994); Klaxon Co. v. Stentor Elec. Mfg. Co., 313 U.S. 487 (1941).

195. See, e.g., ClSG, supra note 7, art. 7(1) (providing that interpreters of the convention must have regard for "the need to promote uniformity in its application"); Convention on Factoring, supra note 182, art. 4(1) (same); Draft Convention on Receivables Financing, supra note 182, art. 8(1) (same); Draft Convention on Security Interests, supra note 182, art. 6(1) (same).

196. Justice Scalia's opinion in Zicherman v. Korean Air Lines Co. once again provides a good contrast. There, the Supreme Court refused to fill a gap in the Warsaw Convention in the form of a rule of federal common law, but only after it first concluded as a factual inatter that the treaty did not "authorize[ national courts to pursue uniformity in derogation of otherwise applicable law." Zicherman, 516 U.S. at 231. Even in matters (such as commercial law) traditionally reserved to the states, such an express direction to pursue international uniformity also overcomes the reluctance of the Supreme Court to find a federal preemption of state law. See Asante Techs., Inc. v. PMC-Sierra, Inc., 164 F. Supp. 2d 1142, 1147-52 (2001) (holding that the uniformity directive in the U.N. Sales Convention evidences an intent by the treaty-lawmakers to preempt state law causes of action for matters within its scope); see also Medtronic, Inc. v. Lohr, 518 U.S. 470, 494 (1996) (citing a "presumption against pre-emption"); New York State Conf. of Blue Cross \& Blue Shield Plans v. Travelers Ins. Co., 514 U.S. 645, 655 (1995) (same); Rice v. Santa Fe Elevator Corp., 331 U.S. 218, 230 (1947) (holding that when Congress legislates in a field traditionally regulated by the states, courts should "start with the assumption that the historic police powers of the States were not to be superseded by the Federal Act unless that was the clear and manifest purpose of Congress").

197. See Van Alstine, supra note 16, at 787-91.

198. See Yoo, Politics as Law, supra note 15 , at $879 \mathrm{n} .85$ (questioning the propriety of this argument as advanced in Dynamic Treaty Interpretation).

199. See El Al 1srael Airlines, Ltd. v. Tsui Yuan Tseng, 525 U.S. 155, 175 (1999) (citing to "decisions of the courts of other Convention signatories" to "corroborate" the Court's interpretation of the Warsaw Convention on air transportation); Air France v. Saks, 470 U.S. 392, 404 (1985) (stating with regard to treaty interpretation that "the opinions of our sister signatories are to be entitled to 
A deliberate and circumscribed delegation to federal courts of an authority to develop the law within the scope of a self-executing treaty is fully consistent with the structure of the Constitution. Such a delegation indeed involves a transfer to the courts of certain powers that the President and Senate could exercise directly. ${ }^{200}$ Parallel to statutory delegation, however, the exercise of these common-law powers does not reflect a unilateral encroachment by the federal courts on powers allocated to other branches, but rather it flows from an intentional and limited transfer by the constitutional treaty-lawmakers themselves. And in this context as well, there are sound reasons for the Supreme Court to conclude, as it has with statutory delegations, that it should not "second-guess" these constitutional lawmakers "regarding the permissible degree of policy judgment that can be left to those ... applying the law."201 Indeed, this observation is consistent with the Court's long-standing jurisprudence, which is equally applicable in the treaty context, that " $[\mathrm{w}]$ hen any Branch acts, it is presumptively exercising the power the Constitution has delegated to it."202

The preeminent role of the executive in foreigu policy matters properly will influence judicial decision-making in the development of the law under some treaties in some circuinstances. This prudential consideration does not, however, undermine the formal constitutional foundation for a circumscribed delegation of power under a treaty. Rather, as we shall examine in more detail in Part III, it merely relates to the degree to which the courts should show deference to the vicws of the executive branch in the situational exercise of that power.

III

\section{The Treaty Power and Deference to the Executive}

The difficulty with much of the commentary on the role of treaties in our constitutional system is the tendency to view all of them as fundamentally the same. As a result, compelling analyses on narrow subjects often dissolve in their express or implied extrapolation. One prominent example of this phenomenon is the common assertion that foreign-policy concerns require that courts defer to the executive branch in all matters of treaty

considerable weight" (quoting Benjamins v. British European Airways, 572 F.2d 913, 919 (1978), cert. denied, 439 U.S. 1114 (1979))); see also RESTATEMENT (THIRD) OF FOREIGN RELATIONS, supra note 93, § 325, cmt. d ("Treaties that lay down rules to be enforced by the parties through their internal courts or administrative agencies should be construed so as to achieve uniformity of result despite differences between national legal systems.").

200. See Yoo, Politics as Law, supra note 15, at 879 n.85 (questioning the constitutionality of treaty delegations of federal common-law authority because it would involve an "enormous transfer" of power from the treatyinakers to the eourts).

201. Mistretta v. United States, 488 U.S. 361,416 (Scalia, J., dissenting). See also supra notes 115-16 and accounpanying text (examining this observation in the statutory context).

202. INS v. Chadha, 462 U.S. 919,951 (1983). 
interpretation. ${ }^{203}$ This is an important point for the analysis here; for, if the executive foreign-affairs powers in Article II somehow radiate to Article III and neutralize the judicial power to interpret the law under treaties, there may be little functional value to a formal delegation of developmental authority to the courts. As we shall see, however, the executive's role in foreign affairs varies in importance according to the type of treaty involved. Furthermore, the Constitution itself suggests that the executive's control in this area is not absolute.

\section{A. The Executive's Role in Foreign Policy}

It is certainly correct that the President has primary responsibility over the international conduct of the United States as a sovereign entity. As Professor Yoo correctly observes, both the text and the drafting history of Article II contemplate that the executive branch would be the primary institution in carrying out the nation's foreign affairs. ${ }^{204}$ And, of course, the initiation of treaties is within the power of the President, subject to Senate consent. Moreover, the exigencies of national defense, the delicacy of international diplomacy, and the need in many circumstances for a unitary voice im foreign relations create strong functionalist arguments for affording substantial discretion to the President on such issues. ${ }^{205}$

The President's authority in matters of foreign policy is not absolute, however. The Senate also plays an integral role in shaping foreign policy, through its advice and consent to the ratification of treaties. ${ }^{206}$ Moreover, the Constitution expressly grants to Congress the powers to declare war, ${ }^{207}$ to regulate foreign commerce, ${ }^{208}$ and to define offenses against international law, ${ }^{209}$ as well as the ultimate authority, under its spending power, ${ }^{210}$

203. See Yoo, Politics as Low, supra note 15, at 873-75.

204. See id. at 873-77.

205. See Yoo, Politics as Law, supra note 15, at 870-77; see also id. at 872 (advancing the functionalist argument that the Framers granted extensive authority to the executive in matters of foreign affairs "[b]ecause of the unitary Executive's perceived superiority to other approaches for addressing the dangers of the international world...."); id. ("In this vast external realm, with its important, complicated, delicate and manifold problems, the President alone has the power to speak or listen as a representative of the nation." (quoting United States v. Curtiss-Wright Exp. Corp., 299 U.S. 304, 319 (1936))).

206. See Arthur Bestor, "Advice" From the Very Beginning, "Consent" When the End Is Achieved, 83 AM. J. INT'L L. 718, 725 (1989) (arguing after an extensive review of its constitutional drafting history that Article II, Section 2, Clause 2, "represents a contmuing constitutional recognition of the Senate's inescapable and indefeasible responsibility-even though now a shared responsibilityfor determining the foreign policy of the nation").

207. U.S. ConsT. art. I, \$ 8, cl. 11 (granting to Congress the power "[t]o declare War, grant Letters of Marque and Reprisal, and make Rules concerning Captures on Land and Water").

208. U.S. ConST. art. $1, \S 8$, cl. 3 (granting to Congress the power "[t]o regulate Commerce with foreign Nations").

209. U.S. Const. art. I, $\$ 8, \mathrm{cl} .10$ (granting to Congress the power "[t]0 define and punish Piracies and Felomies committed on the high Seas, and Offences against the Law of Nations"). 
to withhold funding for foreign activities with which it disagrees. In addition, Congress as a whole also may exercise general authority in this area through traditional Article I legislation, if necessary, by overriding a Presidential veto. Nor are powers expressly allocated to other constitutional institutions somehow transferred to the executive merely because they may affect foreign affairs. As we have seen, the Supreme Court has long confirmed that the determination of individual rights under treaties is fundamentally a judicial responsibility. ${ }^{211}$ More broadly, the Court has made clear that a matter's potential foreign-policy implications do not by themselves transform it into a political question. As it emphatically stated in its famous opinion on the subject in Baker v. Carr, "it is error to suppose that every case or controversy which touches foreign relations lies beyond judicial cognizance."212

On the specific issue of treaty interpretation, even the Rehnquist court has refused to accept assertions that executive interpretations bind the courts. ${ }^{213}$ In United States $v$. Alvarez-Machain, ${ }^{214}$ a highly politicized case in which the Court ultimately agreed with the President's interpretation, for example, the Court observed that if a treaty is self-executing, then "it would appear that a court must enforce it on behalf of an individual regardless of the offensiveness of the practice of one nation to the other."215 In applying this conclusion, federal courts on a number of occasions have refused to accept the interpretation of a treaty asserted by executive-branch officials. ${ }^{216}$

210. U.S. Const. art. I, $\S 9$, cl. 7 (providing that "[n]o Money shall be drawn from the Treasury, but in Consequence of Appropriations made by Law").

21I. See, e.g., Ware v. Hylton, 3 U.S. (3 Dall.) 199, 239 (1796) (opinion of Chase, J.) (concluding with regard to the interpretation of a treaty provision that the courts "were the only proper authority to decide, whether the case was within this article of the treaty, and the operation and effect of it"); see also supra notes 72-80 and accompanying text analyzing Supreme Court authority on the role of the judiciary in the treaty interpretation).

212. 369 U.S. 186, 2 I I (1962); see also Japan Whaling Ass'n v. Am. Cetacean Soc'y, 478 U.S. 221,230 (I986).

We are cognizant of the interplay between [certain statutory provisions] and the conduct of this Nation's foreign relations, and we recognize the premier role which both Congress and the Executive play in this field. But under the Constitution, one of the Judiciary's characteristic roles is to interpret statutes, and we cannot shirk this responsibility merely because our decision may have significant political overtones. Id.

213. See Bederman, supra note 16, at 1016 (concluding after an extensive analysis of the Court's treaty jurisprudence that "the Rehnquist Court has refused to accept the government's position that its interpretations of treaties are privileged and beyond judicial review").

214. 504 U.S. 655 (1992).

215. 504 U.S. at 667; see also Vazquez, Treaty Rights, supra note 48, at 1131 ("It cannot be said that the Constitution allocates decisions of treaty issues generally to branches other than the judiciary.").

216. As Professor Bederman has noted, in Chan v. Korean Air Lines, Ltd., 490 U.S. 122 (1989), for example, the Court interpreted a treaty contrary to the position of the executive branch. See Bederman, supra note 16, at 1018; see also Perkins v. Elg, 307 U.S. 325, 335-42 (1939) (refusing to 
Nonetheless, the Supreme Court on occasion has observed that the executive branch's interpretation of a treaty deserves some deference. In United States v. Stuart, for example, the Court repeated the common formulation that "[a]lthough not conclusive," the interpretive views of the government agencies that have been charged with the negotiation and enforceinent of a treaty are "entitled to great weight." 217 Unfortunately, however, the Court has never offered a coherent explanation of the foundation for this deference, nor consistently adhered to it im practice. ${ }^{218}$ Moreover, woven among the rhetoric of deference is a tendency to approach matters of interpretation as if all treaties solely reflect a contract between sovereigns, ${ }^{219}$ even though the Supreme Court recognized as early as Foster $v$. Neilson that the Constitution rejected the mere "sovereign contract" view of all treaties. ${ }^{220}$ The natural result of this inflexible conception of treaties has been enhanced deference to the executive branch.

Concerns about foreign policy admittedly inject a complicating factor when determining the amount of deference to afford an executive interpretation of a treaty. The difficulty with this point, however, is one of generalization. Not all provisions of all treaties affect our nation's foreign affairs

follow the executive branch's reinterpretation of a naturalization treaty); Valentine v. United States $e x$ rel. Neidecker, 299 U.S. 5, 10 (1936) (disagreeing with a claim that the President had certain implied discretionary powers under an extradition treaty); Rainbow Navigation, Inc. v. Dep't of the Navy, 686 F. Supp. $354,358-60$ (D.D.C. 1988) (interpreting a treaty contrary to the view offered by the executive that it was not self-executing and thus created no rights enforceable by the plaintiff); RESTATEMENT (THIRD) of ForeIGN Relations $\S 326$, supra note 93, Reporters' note 2 (citing United States v. Decker, 600 F.2d 733 (9th Cir. 1979), cert. denied, 444 U.S. 855 (1979), and Umited States v. Enger, 472 F. Supp. 490 (D.N.J. 1978)).

217. United States v. Stuart, 489 U.S. 353, 369 (1989) (quoting Sumitomo Shoji Am., Inc. v. Avagliano, 457 U.S. I76, 184-85 (1982)); see also O'Connor v. United States, 479 U.S. 27, 33 (I986) (stating that executive application of a treaty is entitled to "great weight").

2I8. See Bradley, Chevron Deference, supra note 56, at 665 (observing that "critics have correctly noted that courts do not always defer when a case implicates foreign affairs; if 'foreign affairs' is the touchstone for deference, the case law looks incoherent'); see also supra note 2I6 (citing examples of where federal courts have not followed the interpretive views of the executive branch).

219. Zicherman v. Korean Air Limes Co., 516 U.S. 217, 226 (1996) (stating that treaties reflect "an agreement among sovereign powers"); see also Société Nationale Industrielle Aérospatiale v. Umited States Dist. Court for the S. Dist. of Iowa, 482 U.S. 522, 533 (1987) ("In interpreting an international treaty, we are inindful that it is " $m$ the nature of a contract between nations." (quoting Trans World Airlines, Inc. v. Franklin Mint Corp., 466 U.S. 243, 253 (1984))); Washington v. Wash. Commercial Passenger Fishing Vessel Ass'n, 443 U.S. 658, 675 (1979) ("A treaty ... is essentially a contract between two sovereign nations."); Santovincenzo v. Egan, 284 U.S. 30, 40 (1931) (explaiming that "treaties are contracts between independent nations"). The Supreme Court on occasion has stated that treaties should be interpreted more "liberally than private agreements." Air France v. Saks, 470 U.S. 392, 396 (1985) (quoting Choctaw Nation of Indians v. United States, 318 U.S. 423, 431-32 (1943)). See also E. Airlines, Inc. v. Floyd, 499 U.S. 530, 535 (1991); Volkswagenwerk Aktiengesellschaft v. Schlunk, 486 U.S. 694, 699 (1988). The precise import of this observation, however, is not at all clear. See Wolf, supra note 16, at 1068 (arguing that the norm that treaties should be interpreted "liberally and in good faith ... . may never have been the actual basis of a Supreme Court holding").

220. 27 U.S. 253, 314; see also supra notes 52-80 and accompanying text (analyzing the effect of this observation). 
equally. ${ }^{221}$ Treaties addressing core national defense or diplomatic matters may intrinsically carry important foreign policy implications, for they most often only create rights and obligations of nations inter se. But other treaties establish rights directly enforceable by private individuals that may affect foreign affairs only tangentially or episodically. And still others, as we have seen, do not involve rights or obligations of sovereign states at all; rather, they solely regulate the interaction between private actors. ${ }^{222}$ Only in the most attenuated or contorted definition of the term, or in the most extreme circumstances, will an interpretation of this latter class of treaties infiuence United States foreign policy at all.

\section{B. Calibrated Deference}

The variety of treaties and different degrees of executive involvement suggest that the proper approach to executive interpretations of treaties is one of calibrated deference. For diplomatic and national defense treaties, the deference due executive agencies properly may be substantial. In this context, as Professor Yoo convincingly argues, the executive branch may have significant structural advantages in both understanding the context of a treaty and giving practical meaning to its provisions. ${ }^{223}$ Indeed, as the institution in actual control of the day-to-day operation of those treaties, some level of executive interpretation simply is unavoidable. ${ }^{224}$ For such treaties, entrusting a specific executive-branch agency with the responsibility for the continuing administration of their provisions may reflect an implicit delegation of enhanced interpretive discretion. ${ }^{225}$

221. As Louis Henkin has insightfully observed with regard to the general powers of the executive, "foreign affairs makes a difference." Louls HENKEN, ForEIGN AFFAIRS AND THE UNITED States Constitution 132 (2d ed. 1996); see also Bradley, Chevron Deference, supra note 56, at 66367 (describing the importance of foreign affairs concerns in the Supreme Court's deference to the executive branch).

222. See supra notes $98-106$ and accompanying text.

223. See Yoo, Politics as Law, supra note 15, at 870-77.

224. See W. Michael Reisinan, Necessary and Proper: Executive Competence to Interpret Treaties, 15 YALE J. INT'L L. 316, 325-26 (1990) ("The issue is simply the competence to perform treaties internationally. If you cannot interpret, you cannot perform."); Eugene V. Rostow, The Reinterpretation Debate and Constitutional Law, 137 U. PA. L. Rev. 1451, 1457 (1989) ("The phenomenon of presidential interpretation and reinterpretation of treaties ... occurs daily in every nook and cranny of the law.... Sometimes the changes are imcremental and interstitial. Sometimes they are considerable. They are in fact inevitable as law confronts life every day of the week."); see also Yoo, Politics as Law, supra note 15, at 874 ("Just as the President must interpret international law in the course of managing international relations, so too must the President interpret our treaties as part of the day-to-day execution of foreign affairs.").

225. In the statutory context, the Supreme Court has made clear that Congress has wider latitude in delegating authority to executive-branch agencies in the foreign affairs arena. See Clinton v. City of New York, 524 U.S. 417, 445 (1998) (drawing the same distinction with regard to the constitutionality of the Line-Item Veto Act); United States v. Curtis-Wright Exp. Corp., 299 U.S. 304, 320 (1936) (stating that in matters of foreign affairs the President has "a degree of discretion and freedoin from statutory restriction which would not be admissible were domestic affairs alone involved"); Field v. Clark, 143 U.S. 649, 691 (1892). The Court observed that 
Professor Curtis Bradley has suggested in this regard that the issue of deference to executive treaty interpretations might be resolved by analogy to the Supreme Court's Chevron doctrine. ${ }^{226}$ Under this doctrine, an express congressional delegation to an executive agency of administrative authority over a statute also carries an implied delegation of enhanced interpretative powers. ${ }^{227}$ As a result, courts must defer to the agency's interpretation as long as it is not contrary to the unambiguously expressed intent of Congress and is a "permissible" construction of the statute. ${ }^{228}$ Professor Bradley suggests that the executive's preeminence in the matters of foreign affairs permits an implied delegation approach that parallels the Chevron doctrine. ${ }^{229} \mathrm{He}$ thus argues that an analogy to the Chevron doctrine may both explain and frame the degree of deference due reasonable interpretations of treaties by those executive agencies charged with their administration and enforcement. ${ }^{230}$

Even such an analogy to the Chevron doctrine carries an important internal limitation, however. In the statutory context, the Supreme Court in Chevron and its progeny has made clear that a deliberate congressional delegation of continuing administrative authority over a statutory field is a precondition to the enhanced judicial deference to agency interpretations of the statute. ${ }^{231}$ Even if one properly can extend the doctrine to the treaty context, therefore, an essential predicate for enhanced deference to executive interpretations is an entrustment of continumg administrative authority to a specific agency. A careful reading of Supreme Court rhetoric on treaty interpretation in fact reveals precisely such a requirement: when the Court has referred to deference to the executive branch it has consistently stated as a precondition that the interpretive views must be expressed "by the government agencies charged with their negotiation and enforcement."232

in the judgmeut of the legislative branch of the government, it is often desirable, if not essential for the protection of the interests of our people agaiust the unfriendly or discriminating regulations established by foreign governments ... to invest the president with large discretion in matters arising out of the execution of statutes relating to trade and commerce with other nations

Id.

226. See Bradley, Chevron Deference, supra note 56, at 701-07.

227. Chevron U.S.A. v. Natural Res. Def. Council, 467 U.S. 837 (1984).

228. Id. at 842-43.

229. See Bradley, Chevron Deference, supra note 56, at 667-75.

230. Id. at 701-07.

231. See, e.g., FDA v. Brown and Williamson Tobacco Corp., 529 U.S. 120, 159 (2000) ("Deference under Chevron to an agency's construction of a statute that it administers is premised on the theory that a statute's ambiguity constitutes an implicit delegation from Congress to the agency to fill in the statutory gaps."); Adams Fruit Co. v. Barrett, 494 U.S. 638, 649 (1990) ("A precondition to deference under Chevron is a congressional delegation of administrative authority.").

232. See United States v. Stuart, 489 U.S. 353, 369 (1989) (quoting Sumitomo Shoji Am., Inc. v. Avagliano, 457 U.S. 176, 184-85 (1982)). The Restatement of Foreign Relations overlooks this important qualification. Although it cites to the same Supreme Court authority, it inexplicably states 
Even in the treaty context, this precondition for deference to executive agencies provides a significant limitation. Many treaties, in particular those that create individual rights, may provide only rare opportunities for administration by executive agencies. ${ }^{233}$ For those private-law treaties that only create rights enforceable by and against private entities, ${ }^{234}$ most often there will be no foundation for implied delegation of interpretive authority to the executive at all. Similarly, as the degree to which a treaty implicates foreign affairs concerns decreases, so too should the degree of deference to executive views about the meaning of its provisions. As with the commercial law conventions discussed in Dynamic Treaty Interpretation, where a treaty involves no sovereign obligations and carries only the most attenuated foreign-policy implications, the propriety of dcference should dissolve almost entirely. ${ }^{235}$ In short, without an entrustment of continuing administrative authority to an executive-branch agency, what remains is a slidingscale deference calibrated to the overall persuasiveness of a proffered executive-branch interpretation of a treaty and to any implications for our nation's foreign affairs. ${ }^{236}$

The Supreme Court's most recent pronouncement on the propriety of deference in El Al Israel Airlines, Ltd. v. Tsui Yuan Tseng ${ }^{237}$ is consistent with this reasoning. The case involved the interpretation of the private-law Warsaw Convention on air transportation. On the issue of deference, the Court once again cited the above authority that the views of those executive agencies that are charged with the enforcement of a treaty are entitled to great weight. ${ }^{238}$ But it also characterized the general proposition of deference to executive interpretations in noticeably more careful, measured

without express limitation that courts should afford "great weight to an interpretation made by the Executive Branch." RESTATEMENT (THIRD) OF FoREIGN RELATIONS, supra note 93, §326(2).

233. See Bradley, Chevron Deference, supra note 56, at 706-07 (arguing that "Chevron deference concerning the meaning of a treaty" would not be absolute, but rather "be limited to situations where the executive branch entity has been charged with applying the treaty").

234. See Van Alstine, supra note 16, at 698-99 (describing the variety of private-law treaties that create only individual rights and obligations).

235. Interestingly, the most prominent recent case in which the Supreme Court has not deferred to the executive dealt with interpretation of a treaty provision that governed solely the rights between private entities. See Chan v. Korean Air Lines, Ltd., 490 U.S. 122 (1989) (interpreting the express provisions of the Warsaw Convention on air transportation); see also Bederman, supra note 16, at 1018 (noting that the Supreme Court interpreted the Warsaw Convention contrary to the view of the solicitor general, although the majority opinion in Chan does not mention this fact).

236. This approach is also consistent with the Supreme Court's recent opinions on the propriety of deference to executive-branch interpretations of statutes where the Chevron doctrine does not apply. See Thomas W. Merrill and Kristin E. Hickman, Chevron's Domain, 89 GEo. L.J. 833, 856-63 (2001) (arguing that recent Supreme Court precedent suggests that even when Chervon does not apply, federal courts should give deference to executive agency interpretations of statutes based on their overall persuasiveness) (citing and analyzing in this regard Skidmore v. Swift \& Co., 323 U.S. 134, 140 (1944)).

237. 525 U.S. 155 (1999).

238. 525 U.S. at 168 (citing and quoting Sumitomo Shoji Am., Inc. v. Avagliano, 457 U.S. 176, 184-185(1982)). 
tones. The Court described the proper principle merely as one of "respect" for the executive, and it stated that this respect is only "ordinarily" due to the "reasonable" views of the executive branch concerning the meaning of a treaty. ${ }^{239}$

Assertions that treaty law is fundamentally executive in nature (even if accepted) do not undermine this conclusion. In the parallel constitutional situation of Article I legislation, Congress is the preeminent decisionmaking mstitution. Nonetheless, as we have seen, ${ }^{240}$ the Supreme Court has made clear that a subsequent Congress does not have the authority to interpret earlier legislation without adhering to the full constitutional process for the creation of binding legal norms (that is, without passing a law signed by, or over the veto of, the President). ${ }^{241}$ In the same way, the opinions of later executive-branch officials as to the ineaning of an earlier selfexecuting treaty are constitutionally suspect, for they also do not undergo the process prescribed in Article II for the creation of treaty law. ${ }^{242}$

Finally, arguments founded on presumed executive expertise likewise do not justify anything more than calibrated deference. On delicate matters of international diplomacy and national defense, the structural advantages and resultant expertise of the executive may support substantial deference on treaty interpretation matters. For other treaties, however, there may be no reason to assume any special executive-branch expertise. The commercial law treaties analyzed in Dynamic Treaty Interpretation once again provide good examples. The subjects of these conventions are detailed matters of commercial law, such as the imternational sale of goods, receivables financing, and security interests in moveable equipment. ${ }^{243}$ Experts in the respective fields draft such private-law treaties under the auspices of permanent international institutions, some of which are nongovernmental. ${ }^{244}$ Indeed, this drafting process substantially parallels the

239. Id.

240. See supra notes $86-87$ and accompanying text.

241. See, e.g., United States v. Southwestern Cable Co., 392 U.S. 157, 170 (1968) (holding that the interpretive views of a later Congress are of "very little, if any, significance" (quoting Rainwater v. United States, 356 U.S. 590, 593 (1958)); see also Cent. Bank of Denver, N.A. v. First Interstate Bank of Denver, N.A., 511 U.S. 164, 185 (1994) (holding that an interpretation of Congress regarding the interpretation of an earlier statute "is of little assistance in discerning the meaning of that statute" (quoting Pub. Employees Ret. Sys. of Ohio v. Betts, 492 U.S. 158, 168 (1989))).

242. The Supreme Court has made the same observation with regard to subsequent Senate interpretations of earlier treaties. See Fourteen Diamond Rings v. United States, 183 U.S. 176, 180 (1901) ("The meaning of the treaty cannot be controlled by subsequent explanations of some of those who inay have voted to ratify it.").

243. See, e.g., CISG, supra note 7, arts. 1-3; Convention on Financial Leasing, supra note 182, arts. 1-2; Convention on Factoring, supra note 182, arts. 1-2; Convention on Agency, supra note 182, art. 1; Convention on Security Interests, supra note 182, arts. 1-4.

244. There are three principal institutions involved $\mathrm{m}$ the drafting of treaties in the field of private law. The first, a formal body that operates under the auspices of the United Nations, is UNCITRAL. For infornation on the workings of UNCITRAL in general, see John Honnold, The United Nations Commission on International Trade Law: Mission and Methods, 27 AM. J. CoMP. L. 201 (1979). The 
processes for drafting many domestic commercial law statutes. ${ }^{245}$ Although representatives of the State Department also oversee the process, ${ }^{246}$ private experts, generally law professors, are often the principal representatives of the United States in the drafting of the substantive provisions of these commercial law treaties. ${ }^{247}$

Functional arguments founded on executive preeminence in foreign affairs thus do not mandate absolute judicial acquiescence to executive-branch interpretations of all treaties. Respect for the executive's important role in the conduct of foreign affairs will justify calibrated judicial deference to the reasonable interpretation of treaties with foreignaffairs implications. It may also be appropriate to grant enhanced deference to executive interpretations where the treaty-lawmakers have entrusted the continuing administration of a treaty to a particular executive agency. But this respect for the reasonable views of the executive does not displace the core judicial responsibility to interpret treaties that create domestically enforceable rights, nor does it invalidate a properly circumscribed delegation of authority to the courts to develop the law within their scope.

second is a private organization, The Hague Conference on Private International Law, which has focused primarily on conventions governing civil procedure and domestic relations. For examples of treaties drafted by this body that have been ratified by the United States, see supra notes 5-6 and accompanying text. The final institution, also private, is the International Institute for the Unification of Private Law, commonly known by its French acronym, UNIDROIT. This body originally came into being as an entity affiliated with the League of Nations but is now an independent organization with headquarters in Rome. See International Institute for the Unification of Private Law, Mar. I5, 1940, 15 U.S.T. 2494 (entered into force for the United States on Mar. 13, 1964). Through special legislation in 1963 , Congress officially authorized U.S. participation in UNIDROIT. See 22 U.S.C. $\$ 269 \mathrm{~g}(200 \mathrm{I})$. For more information on the work of these bodies, see Van Alstine, supra note I6, at 694-700.

245. For a review of the Uniform Commercial Code drafting process referenced here, see A. Brook Oberby, Modeling U.C.C. Drafting, 29 LoY. L.A. L. Rev. 645, $652-56$ (I996) (describing the drafting process for the revision of the Uniform Commercial Code); William J. Woodward, Jr., Private Legislation in the United States-How the Uniform Commercial Code Becomes Law, 72 TEMP. L. Rev. 451 (1999) (describing the work of the American Law Institute and the quasi-public National Council of Commissioners on Uniform State Laws). See also Paul B. Stephen, The Futility of Unification and Harmonization in International Commercial Law, 39 VA. J. INT'L L. 743, 749-53 (1999) (describing the drafting process for international commercial law).

246. See Peter H. Pfund, Contributing to Progressive Development of Private International Law: The International Process and the United States Approach, 249 RecueIL Des Cours 9, 51-75 (1994) (describing the drafting process for a variety of private-law treaties and noting the involvement of the Office of the Legal Advisor for Private International Law of the State Department).

247. See id. at 55-57 (relaying an observation by the principal State Department official involved in such projects that the drafting work required "specialized expertise [which is] available in the United States almost exclusively in the private legal and business sectors, in law schools, and in the interest groups representing the particular industry, branch of business or other activity"); see also Alejandro M. Garro, Reconciliation of Legal Traditions in the U.N. Convention on Contracts for the International Sale of Goods, 23 INT'L LAw 443, 484 n.9 (1989) (noting that the principal representatives of the United States in the drafting of the U.N. Sales Convention were Professors Alan Farnsworth and John Honnold, in addition to a representative of the State Department, Peter Pfund). 


\section{CONCLUSION}

The subject of the interpretation of treaties is sure to become an increasingly contentious one. Just as the growth of statutes into this nation's "primary source of law"248 propelled statutory interpretation into one of the most animated theines of legal scholarship, so too does the rise of treaty law promise to spawn increasmgly heated academic debate. One aspect of the treaty power that thus far has largely escaped scholarly and judicial attention is the authority of the treaty-lawmakers (the President, with the consent of the Senate) to delegate developinental powers to the federal courts. In this light, Professor Yoo's call for more intense scrutiny of the constitutional foundation for such an authority is to be welcomed. I have argued here that, parallel to an established principle in the statutory context, a deliberate and circumscribed delegation of authority to develop the law within the scope of a self-executing treaty fully coinports with both the text and structure of the Constitution. Indeed, a whole range of private-law treaties, some ratified, others waiting to be, already expressly contain such a delegation. As this and other issues of treaty law continue to gain prominence in our domestic legal system, this debate sounds a call to judges and scholars for substantially more analysis of the proper role of the judiciary in the interpretation of treaties as one part of "the supreme Law of the Land." 249 
